\title{
Review
}

International Axchives of
Allergy
Immunology

\section{HLA and Delayed Drug-Induced Hypersensitivity}

\author{
Bernardo Sousa-Pinto ${ }^{a, b}$ Cláudia Correia ${ }^{a}$ Lídia Gomes $^{a}$ Sara Gil-Mata ${ }^{a}$ \\ Luís Araújo ${ }^{a, c}$ Osvaldo Correia ${ }^{a, d}$ Luís Delgado ${ }^{a-c}$ \\ a Laboratory of Immunology, Basic and Clinical Immunology Unit, and ${ }^{\mathrm{b}}$ Center for Research in \\ Health Technologies and Information Systems (CINTESIS), Faculty of Medicine, University of Porto, \\ and ${ }^{\mathrm{C} A l l e r g y}$ Unit and ${ }^{\mathrm{d}}$ Epidermis Dermatology Center, CUF Institute, Porto, Portugal
}

\section{Key Words}

Delayed allergy · Drug allergy · Genetic testing ·

Histocompatibility antigens · Major histocompatibility

complex Pharmacogenetics

\begin{abstract}
Delayed drug allergy reactions (DDAR) are potentially fatal. Certain human leukocyte antigen (HLA) alleles have been associated with delayed allergy reactions following the administration of particular drugs. Examples are HLA-B*57:01 (abacavir), HLA-B*15:02/HLA-A*31:01 (carbamazepine), and HLA-B*58:01 (allopurinol). Based on the identification of these associations, it may now be possible to prevent certain allergy reactions that were, until recently, considered unpredictable. In this review, we will focus on the pharmacogenetics of the best-studied associations between specific HLA alleles and delayed allergy reactions and describe the pathogenesis models proposed so far. Finally, we will evaluate the genetic screening strategies available and discuss the clinical relevance of a better understanding of the immunogenetics and mechanisms involved in DDAR.
\end{abstract}

(c) 2016 S. Karger AG, Basel
(2) 2016 S. Karger AG, Basel

$1018-2438 / 16 / 1703-0163 \$ 39.50 / 0$

\section{Introduction}

Adverse drug reactions can be classified into type A reactions, which are based on the pharmacological action of the drug and hence predictable, and type B reactions, which are largely related to host genetics and immunological hypersensitivity and, therefore, less dependent on drug dose $[1,2]$. Type B reactions include drug-induced T-cell-mediated hypersensitivity syndromes, consisting of 'delayed drug allergy reactions' (DDAR) as defined by World Allergy Organization nomenclature [3-5]. DDAR comprise a heterogeneous group of distinct clinical syndromes, including severe cutaneous adverse reactions (SCAR), encompassing acute generalized exanthematous pustulosis, drug reactions with eosinophilia and systemic symptoms (DRESS), and Stevens-Johnson syndrome (SJS)/toxic epidermal necrolysis (TEN) $[3,4,6]$. Additionally, DDAR can also predominantly affect particular organs other than the skin and mucosae, with the liver being the most commonly involved, with manifestations ranging from a mild self-limited presentation to a fulminant liver failure episode [7]. Its clinical features and immunopathogenic mechanisms are out of scope of this article and have been reviewed elsewhere [7] (see also table 1).

Concerning SJS and TEN, both conditions are characterized by keratinocyte apoptosis with nearly absent

\section{KARGER}

E-Mail karger@karger.com

www.karger.com/iaa
Correspondence to: Dr. Bernardo Sousa-Pinto

Laboratory of Immunology, Basic and Clinical Immunology Unit, Faculty of Medicine Alameda Prof. Hernâni Monteiro

PT-4200-319 Porto (Portugal)

E-Mail bernardo@med.up.pt 
Table 1. Associations between specific delayed drug allergy reactions (DDAR) and HLA alleles according to the ethnic group and pattern of reactions

\begin{tabular}{|c|c|c|c|c|c|}
\hline Drug & Ethnic group & $\begin{array}{l}\text { Pattern of } \\
\text { reactions }\end{array}$ & Allele & $\begin{array}{l}\text { Odds ratio }{ }^{\mathrm{a}} \\
\text { ( } 95 \% \text { confidence interval) }\end{array}$ & $\begin{array}{l}\text { Ref. } \\
\text { No. }\end{array}$ \\
\hline \multirow[t]{3}{*}{ Abacavir } & Afro-American & AAS & HLA-B*57:01 & $\begin{array}{c}11.10(3.78-32.63)^{\mathrm{b}} \\
899.80(38.47-21,045.27)^{\mathrm{c}}\end{array}$ & 48 \\
\hline & Caucasian & AAS & HLA-B*57:01 & $\begin{array}{c}31.92(21.67-47.02)^{\mathrm{b}} \\
1,507.01(200.78-11,311.25)^{\mathrm{c}}\end{array}$ & 48 \\
\hline & Hispanic & AAS & HLA-B*57:01 & $17.58(3.85-80.37)$ & 48 \\
\hline \multirow[t]{11}{*}{ Allopurinol } & Caucasian & SCAR & HLA-A*33:03 & $105.00(4.48-2,461.61)^{\mathrm{d}}$ & 108 \\
\hline & & & HLA-B*58:01 & $39.11(4.49-340.51)$ & 88 \\
\hline & & & HLA-C*03:02 & $105.00(4.48-2,461.61)^{\mathrm{d}}$ & 108 \\
\hline & Han Chinese & SCAR & HLA-A*33:03 & $9.25(4.46-19.20)$ & 83 \\
\hline & & & HLA-B*58:01 & $580.32(34.43-9,780.93)$ & \\
\hline & & & HLA-C*03:02 & $97.68(27.61-345.51)$ & \\
\hline & Japanese & SCAR/EM & HLA-B*58:01 & $65.6(2.9-1,497.0)$ & 109 \\
\hline & Korean & SCAR & HLA-A*33:03 & $20.5(5.4-78.6)$ & 86 \\
\hline & & & HLA-B*58:01 & $97.8(18.3-521.5)$ & \\
\hline & & & HLA-C*03:02 & $82.1(15.8-426.5)$ & \\
\hline & Thai & SCAR & HLA-B*58:01 & $348.3(19.2-6,336.9)$ & 84 \\
\hline \multirow{6}{*}{$\begin{array}{l}\text { Amoxicillin- } \\
\text { clavulanate }\end{array}$} & Caucasian & DILI & HLA-A*02:01 & $2.2(1.6-3.2)^{\mathrm{d}}$ & 110 \\
\hline & & & HLA-A*30:02 & $2.87(1.42-5.78)^{\mathrm{d}}$ & 111 \\
\hline & & & HLA-DQA $1 * 01: 02$ & $2.0(1.2-4.2)^{\mathrm{d}}$ & 110 \\
\hline & & & HLA-DQB1*06:02 & $10.10(3.59-28.40)^{\mathrm{d}}$ & 112 \\
\hline & & & HLA-DRB1*15:01 & $7.56(2.85-20.03)^{\mathrm{d}}$ & 112 \\
\hline & & & HLA-DRB5*01:01 & $7.56(2.85-20.03)^{\mathrm{d}}$ & 112 \\
\hline Anti-tubercular & Korean & DRESS & HLA-C*04:01 & $6.90(2.20-21.66)$ & 113 \\
\hline \multirow[t]{31}{*}{ Carbamazepine } & Caucasian & SJS/TEN & HLA-A*31:01 & $7.9(2.7-23.6)$ & 75 \\
\hline & & DRESS & HLA-A*31:01 & $24.1(9.6-60.3)$ & 75 \\
\hline & & & HLA-B*07:02 & $0.083(0-0.646)$ & 114 \\
\hline & Han Chinese & MPE & HLA-A*02:01 & $3.16(1.05-9.49)$ & 115 \\
\hline & & SJS/TEN & HLA-A*24:02 & $0.23(0.1-0.6)$ & 116 \\
\hline & & & HLA-A*33:03 & $12.92(3.58-46.59)$ & 117 \\
\hline & & & HLA-B*15:02 & $115.32(18.17-732.13)$ & 118 \\
\hline & & & HLA-B*15:11 & $31.00(2.74-350.50)^{\mathrm{d}}$ & 119 \\
\hline & & & HLA-B*40:01 & $0.16(0.1-0.4)$ & 116 \\
\hline & & & HLA-B*58:01 & $4.96(1.26-19.49)$ & 117 \\
\hline & & & HLA-C*01:02 & $0.26(0.1-0.6)$ & 116 \\
\hline & & & HLA-C*03:02 & $4.96(1.26-19.49)$ & 117 \\
\hline & & & HLA-C*08:01 & $86.8(29.3-254.6)$ & 116 \\
\hline & & & HLA-DQB1*03:03 & $3.12(1.14-8.54)$ & 117 \\
\hline & & & HLA-DRB1*04:05 & $0.08(0.01-0.5)$ & 116 \\
\hline & & & HLA-DRB1*07:01 & $4.64(1.57-13.71)$ & 117 \\
\hline & & & HLA-DRB1*12:02 & $11.4(5.6-22.9)$ & 116 \\
\hline & & $\overline{\text { DRESS }}$ & HLA-A*31:01 & $23.0(4.2-125)$ & 75 \\
\hline & & & HLA-B*51:01 & $3.94(1.2-12.8)$ & 76 \\
\hline & Indian & SJS/TEN & HLA-B*15:02 & $16.67(1.70-162.96)$ & 120 \\
\hline & Japanese & SJS/TEN, & HLA-A*02:06 & $0.1(0.0-0.6)$ & 74 \\
\hline & & $\mathrm{MPE}$, and & HLA-A*31:01 & $10.8(5.9-19.6)$ & 74 \\
\hline & & EM & HLA-B*51:01 & $4.90(1.22-19.69)$ & 121 \\
\hline & & SJS/TEN & HLA-B*15:11 & $9.76(2.01-47.5)^{\mathrm{d}}$ & 122 \\
\hline & & SCAR & HLA-B*39:02 & $9.18(1.58-53.12)^{\mathrm{d}}$ & 123 \\
\hline & Korean & SCAR & HLA-A*31:01 & $7.3(2.3-22.5)$ & 124 \\
\hline & & SIS/TEN & HLA-B*15:11 & $18.0(2.3-141.2)$ & 124 \\
\hline & Malay & SJS/TEN & HLA-B*15:02 & $16.15(4.57-62.4)^{\mathrm{d}}$ & 125 \\
\hline & Thai & SJS/TEN & HLA-B*15:02 & $54.43(16.28-181.96)$ & 118 \\
\hline & Vietnamese & SJS/TEN & HLA-B*15:02 & $33.78(7.55-151.03)$ & 126 \\
\hline & & $\begin{array}{l}\text { SJS/TEN } \\
\text { and DRESS }\end{array}$ & HLA-B*46:01 & $0.27(0.08-4.86)$ & 126 \\
\hline
\end{tabular}


Table 1 (continued)

\begin{tabular}{|c|c|c|c|c|c|}
\hline Drug & Ethnic group & $\begin{array}{l}\text { Pattern of } \\
\text { reactions }\end{array}$ & Allele & $\begin{array}{l}\text { Odds ratio }{ }^{\mathrm{a}} \\
\text { (95\% confidence interval) }\end{array}$ & $\begin{array}{l}\text { Ref. } \\
\text { No. }\end{array}$ \\
\hline Dapsone & Han Chinese & $\begin{array}{l}\text { Fever, rash, } \\
\text { and systemic } \\
\text { symptoms }\end{array}$ & $\begin{array}{l}\text { HLA-B*13:01 } \\
\text { HLA-C*03:04 }\end{array}$ & $\begin{array}{c}20.53(11.55-36.48) \\
9.00(5.87-15.50)\end{array}$ & 127 \\
\hline Flucloxacillin & Caucasian & DILI & $\begin{array}{l}\text { HLA-B*57:01 } \\
\text { HLA-DRB1*07:01 }\end{array}$ & $\begin{array}{r}80.6(22.8-248.9)^{\mathrm{d}} \\
7.2(3.15-16.45)^{\mathrm{d}}\end{array}$ & 128 \\
\hline \multirow[t]{3}{*}{ Lamotrigine } & $\begin{array}{l}\text { Caucasian } \\
\text { (predominantly) }\end{array}$ & SCAR & $\begin{array}{l}\text { HLA-A*68:01 } \\
\text { HLA-B*58:01 } \\
\text { HLA-DQB1*06:09 }\end{array}$ & $\begin{array}{l}19.22(1.01-365) \\
9.45(2.76-32.32)^{\mathrm{d}} \\
5.80(1.40-24.07)^{\mathrm{d}}\end{array}$ & 129 \\
\hline & Han Chinese & SJS/TEN & $\begin{array}{l}\text { HLA-B*13:01 } \\
\text { HLA-B*15:02 } \\
\text { HLA-C }{ }^{*} 08: 01 \\
\text { HLA-DRB1*16:02 }\end{array}$ & $\begin{array}{l}3.7(1.4-10.0) \\
5.1(1.8-15.1) \\
3.0(1.1-7.8) \\
4.3(1.4-12.8)\end{array}$ & 130 \\
\hline & & $\begin{array}{l}\text { SJS/TEN } \\
\text { and MPE }\end{array}$ & $\begin{array}{l}\text { HLA-B* } 15: 19 \\
\text { HLA-B*44:08 } \\
\text { HLA-B*55:01 } \\
\text { HLA-B*81:01 }\end{array}$ & $\begin{array}{l}24.78(1.50-408.76)^{\mathrm{d}} \\
24.78(1.50-408.76)^{\mathrm{d}} \\
24.78(1.50-408.76)^{\mathrm{d}} \\
27.05(1.64-447.38)^{\mathrm{d}}\end{array}$ & 131 \\
\hline Lapatinib & $\begin{array}{l}\text { Multiethnic } \\
\text { (predominantly } \\
\text { Caucasian) }\end{array}$ & DILI & $\begin{array}{l}\text { HLA-DQA } 1 * 02: 01 \\
\text { HLA-DQB1 }{ }^{*} 02: 02 \\
\text { HLA-DRB1 }{ }^{*} 07: 01\end{array}$ & $\begin{array}{c}2.6(1.1-5.7) \\
2.9(1.3-6.6) \\
22.5(6.9-74.1)\end{array}$ & $\begin{array}{l}132 \\
132 \\
133\end{array}$ \\
\hline Lumiracoxib & $\begin{array}{l}\text { Multiethnic } \\
\text { (predominantly } \\
\text { Caucasian) }\end{array}$ & DILI & $\begin{array}{l}\text { HLA-DQA }{ }^{*} 01: 02 \\
\text { HLA-DQB1*06:02 } \\
\text { HLA-DRB1 }{ }^{*} 15: 01 \\
\text { HLA-DRB5 }{ }^{*} 01: 01\end{array}$ & $\begin{array}{l}6.3(4.1-9.6) \\
6.9(4.6-10.3) \\
7.5(5.0-11.3) \\
7.2(4.8-10.8)\end{array}$ & 134 \\
\hline \multirow[t]{2}{*}{ Methazolamide } & Han Chinese & SJS/TEN & $\begin{array}{l}\text { HLA-B*59:01 } \\
\text { HLA-C*01:02 }\end{array}$ & $\begin{array}{c}305.0(11.3-8,259.9) \\
12.1(1.3-111.7) \\
\end{array}$ & 135 \\
\hline & Korean & SJS/TEN & $\begin{array}{l}\text { HLA-B*59:01 } \\
\text { HLA-C*01:02 }\end{array}$ & $\begin{array}{c}249.8(13.4-4,813.5) \\
22.1(1.2-414.3)\end{array}$ & 136 \\
\hline \multirow[t]{6}{*}{ Nevirapine } & $\frac{\text { Black }}{\text { Caucasian }}$ & $\begin{array}{l}\text { SJS/TEN } \\
\text { Skin rash and } \\
\text { systemic or } \\
\text { organ-specific } \\
\text { symptoms }\end{array}$ & $\begin{array}{l}\text { HLA-C }{ }^{*} 04: 01 \\
\text { HLA-B* } 14 \\
\text { HLA-C*08 } \\
\text { HLA-DRB1*01:02 }\end{array}$ & $\begin{array}{c}17.52(3.31-92.8) \\
30.0(5.06-177.71) \\
30.0(5.06-177.71) \\
15.56(2.49-97.34)\end{array}$ & $\begin{array}{r}137 \\
65\end{array}$ \\
\hline & & $\begin{array}{l}\text { Skin rash } \\
\text { Skin rash and } \\
\text { hepatitis }\end{array}$ & $\begin{array}{l}\text { HLA-DRB1*01:01 } \\
\text { HLA-DRB1*01:01 }\end{array}$ & $\frac{70.0(3.65-1,342.66)}{4.77(1.55-14.73)}$ & $\begin{array}{r}138 \\
60\end{array}$ \\
\hline & Han Chinese & $\begin{array}{l}\text { DILI } \\
\text { Skin rash and } \\
\text { systemic or } \\
\text { organ-specific } \\
\text { symptoms }\end{array}$ & $\begin{array}{l}\text { HLA-DRB1*01:01 } \\
\text { HLA-C }{ }^{*} 04\end{array}$ & $\frac{3.02(1.66-5.49)}{3.61(1.13-11.49)}$ & $\begin{array}{l}139 \\
140\end{array}$ \\
\hline & $\begin{array}{l}\text { Indian } \\
\text { Multiethnic }\end{array}$ & $\begin{array}{l}\text { Skin rash } \\
\text { Skin rash and } \\
\text { hepatitis }\end{array}$ & $\begin{array}{l}\text { HLA-B*35 } \\
\text { HLA-C*04 }\end{array}$ & $\frac{3.38(1.54-7.41)}{2.51(1.73-3.62)}$ & $\begin{array}{l}141 \\
139\end{array}$ \\
\hline & $\begin{array}{l}\text { Multiethnic } \\
\text { (predominantly } \\
\text { Black African) }\end{array}$ & DILI & $\begin{array}{l}\text { HLA-B*58:01 } \\
\text { HLA-C }{ }^{*} 02: 10 \\
\text { HLA-C }{ }^{*} 03: 02 \\
\text { HLA-C }{ }^{*} 12: 03 \\
\text { HLA-DRB1*01:02 }\end{array}$ & $\begin{array}{l}3.15(1.23-8.06) \\
0.17(0.04-0.77) \\
4.20(1.01-17.52) \\
4.34(1.24-15.13) \\
4.56(1.30-15.95)\end{array}$ & 142 \\
\hline & Thai & Skin rash & $\begin{array}{l}\text { HLA-B*35:05 } \\
\text { HLA-C*04 }\end{array}$ & $\begin{array}{c}16.53(2.74-98.98) \\
3.18(1.22-8.63)\end{array}$ & $\begin{array}{r}62 \\
143 \\
\end{array}$ \\
\hline \multirow{3}{*}{$\begin{array}{l}\text { NSAIDs and } \\
\text { 'cold medication' }\end{array}$} & $\frac{\text { Brazilian }}{\text { Indian }}$ & $\begin{array}{l}\text { SJS/TEN } \\
\text { SIS/TEN }\end{array}$ & $\begin{array}{l}\text { HLA-B*44:03 } \\
\text { HLA-B*44.03 }\end{array}$ & $\frac{2.74(1.12-6.71)^{\mathrm{d}}}{12.25(3.57-42.01)^{\mathrm{d}}}$ & $\begin{array}{l}144 \\
144\end{array}$ \\
\hline & Japanese & SJS/TEN & $\begin{array}{l}\text { HLA-B*4-A*02:06 } \\
\text { HLA-A*24:02 } \\
\text { HLA-B*44:03 }\end{array}$ & $\begin{array}{l}5.71(3.67-8.88)^{\mathrm{d}} \\
0.49(0.33-0.73)^{\mathrm{d}} \\
4.22(1.59-11.19)^{\mathrm{d}}\end{array}$ & $\begin{array}{l}144 \\
145\end{array}$ \\
\hline & Korean & SJS/TEN & HLA-A*02:06 & $3.00(1.18-7.57)^{\mathrm{d}}$ & 144 \\
\hline
\end{tabular}


Table 1 (continued)

\begin{tabular}{|c|c|c|c|c|c|}
\hline Drug & Ethnic group & $\begin{array}{l}\text { Pattern of } \\
\text { reactions }\end{array}$ & Allele & $\begin{array}{l}\text { Odds ratio }{ }^{\mathrm{a}} \\
\text { ( } 95 \% \text { confidence interval) }\end{array}$ & $\begin{array}{l}\text { Ref. } \\
\text { No. }\end{array}$ \\
\hline \multirow[t]{10}{*}{ Oxcarbazepine } & \multirow[t]{10}{*}{ Han Chinese } & \multirow[t]{10}{*}{ MPE } & HLA-B*13:02 & $7.83(2.32-26.41)^{\mathrm{d}}$ & 146 \\
\hline & & & HLA-B*15:02 & $8.8(1.85-41.79)^{\mathrm{d}}$ & 147 \\
\hline & & & HLA-B*15:19 & $124.2(4.94-3,117.64)^{\mathrm{d}}$ & 146 \\
\hline & & & HLA-B*15:27 & $40.54(3.56-461.64)^{\mathrm{d}}$ & 146 \\
\hline & & & HLA-B*15:58 & $22.85(2.01-259.72)^{\mathrm{d}}$ & 148 \\
\hline & & & HLA-B*27:04 & $5.73(1.13-28.93)$ & 146 \\
\hline & & & HLA-B*27:09 & $124.2(4.94-3,117.64)^{\mathrm{d}}$ & 146 \\
\hline & & & HLA-B*38:02 & $6.33(1.78-22.46)^{\mathrm{d}}$ & 148 \\
\hline & & & HLA-B*48:04 & $124.2(4.94-3,117.64)^{\mathrm{d}}$ & 146 \\
\hline & & & HLA-B*56:01 & $22.85(2.01-259.72)^{\mathrm{d}}$ & 148 \\
\hline \multirow[t]{5}{*}{ Phenytoin } & \multirow[t]{4}{*}{ Han Chinese } & \multirow[t]{4}{*}{ SJS/TEN } & HLA-B*13:01 & $3.7(1.4-10.0)$ & 130 \\
\hline & & & HLA-B*15:02 & $5.1(1.8-15.1)$ & \\
\hline & & & HLA-C*08:01 & $3.0(1.1-7.8)$ & \\
\hline & & & HLA-DRB1*16:02 & $4.3(1.4-12.8)$ & \\
\hline & Thai & SJS/TEN & HLA-B*15:02 & $18.50(1.82-188.40)$ & 149 \\
\hline \multirow[t]{3}{*}{ Sulfamethoxazole } & \multirow[t]{3}{*}{ Thai } & \multirow[t]{3}{*}{ SJS/TEN } & HLA-B*15:02 & $3.91(1.42-10.92)$ & 150 \\
\hline & & & HLA-C*06:02 & $11.84(1.24-566.04)$ & \\
\hline & & & HLA-C*08:01 & $3.53(1.21-10.40)$ & \\
\hline \multirow[t]{5}{*}{ Sulfasalazine } & \multirow[t]{5}{*}{ Han Chinese } & \multirow[t]{5}{*}{ DRESS } & HLA-B*07:02 & $5.80(3.10-108.60)$ & 151 \\
\hline & & & HLA-B*13:01 & $13.00(1.76-95.80)$ & \\
\hline & & & HLA-B*15:05 & $5.80(3.10-108.60)$ & \\
\hline & & & HLA-B*39:01 & $33.89(1.39-826.08)$ & \\
\hline & & & HLA-B*58:01 & $5.80(3.10-108.60)$ & \\
\hline \multirow[t]{5}{*}{ Ticlopidine } & \multirow[t]{5}{*}{ Japanese } & \multirow[t]{5}{*}{ DILI } & HLA-A*33:03 & $13.04(4.40-38.59)$ & 152 \\
\hline & & & HLA-B*44:03 & $6.65(2.38-18.55)$ & \\
\hline & & & HLA-C*14:03 & $7.30(2.59-20.61)$ & \\
\hline & & & HLA-DRB1*13:02 & $9.00(3.10-26.17)$ & \\
\hline & & & HLA-DQB1*06:04 & $10.13(3.42-30.05)$ & \\
\hline
\end{tabular}

AAS = Abacavir allergy syndrome (general malaise, fever, skin rash, fatigue, and gastrointestinal or respiratory symptoms); DILI = drug-induced liver injury; DRESS = drug reactions with eosinophilia and systemic symptoms; EM = erythema multiforme; $\mathrm{MPE}=$ maculopapular exanthema; SCAR = severe cutaneous adverse reactions; SJS/TEN = Stevens-Johnson syndrome/toxic epidermal necrolysis.

${ }^{a}$ Unless otherwise specified, odds ratios are obtained comparing delayed drug allergy cases with drug-tolerant controls. ${ }^{b} \mathrm{Di}-$ agnosis of abacavir allergy performed by clinical criteria only. ${ }^{c}$ Diagnosis of abacavir allergy performed by epicutaneous tests. ${ }^{\mathrm{d}}$ Odds ratio calculated using healthy controls from the general population.

dermal inflammation and subsequent epidermal detachment. The extent of the affected skin area $-<10 \%$ in SJS, $10-30 \%$ in SJS/TEN overlap syndrome, and $>30 \%$ in TEN $[6,8]$ - determines the different prognoses of these conditions, with mortality rates in the range of $1-5 \%$ for SJS and $25-35 \%$ for TEN [9-11]. Early symptoms of both SJS and TEN include influenza-like symptoms. These can last from anywhere between 1 day and 2 weeks, and are followed by skin lesions that first appear on the trunk and then on the neck, face, and proximal upper limbs $[9,10]$. Because SJS and TEN present with mucocutaneous manifestations, they were traditionally considered to be more severe forms of erythema multiforme. Nevertheless, this notion was abandoned with the identification of demographic and etiologic differences between SCAR and ery- thema multiforme (erythema multiforme, for example, although sometimes drug related, is mostly associated with herpes infections) [12].

Although DRESS is also characterized by cutaneous manifestations, its diagnosis is challenging, since its symptoms mimic those of many other disorders. Several tools have been developed to facilitate the diagnosis of DRESS, including the European Registry of Severe Cutaneous Adverse Reactions to Drugs and Collection of Biological Samples (RegiSCAR) and the diagnostic criteria established by the Japanese consensus group led by Shiohara [13] in 2007 as well as other criteria [14]. Although there are typical patterns of the mucocutaneous signs of DDAR (fig. 1), the diagnosis of these conditions is further complicated by the existence of concomitant syndromes, 


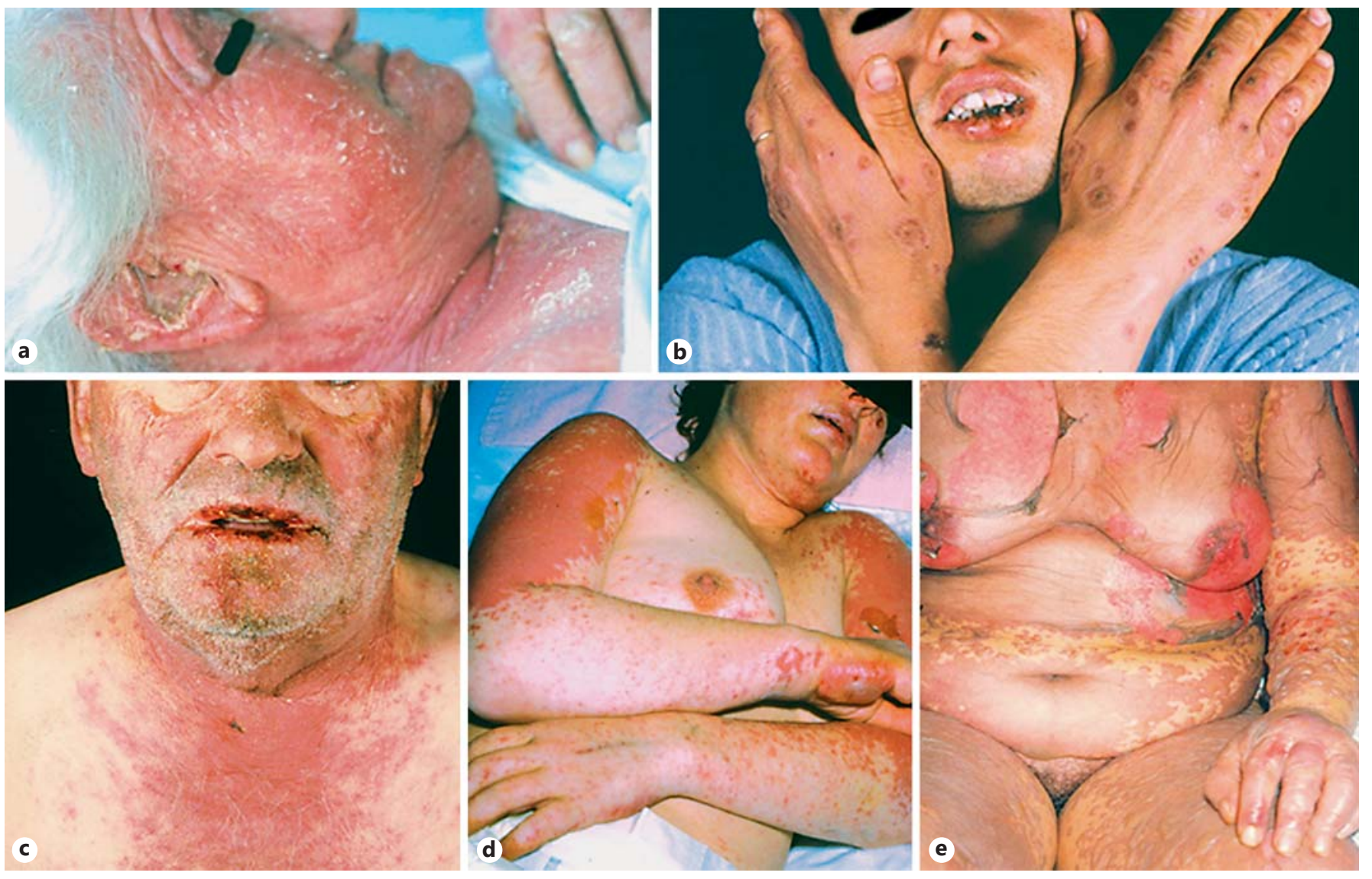

Fig. 1. Typical patterns of the mucocutaneous signs of DDAR. a DRESS induced by allopurinol. b Erythema multiforme related to herpes simplex infection with typical target lesions. c SJS due to trimethoprim-sulfamethoxazole for a urinary tract infection with atypical skin target lesions and mucosal involvement. d SJS/TEN overlap in a HIV + patient related to trimethoprim-sulfamethoxazole. e TEN induced by piroxicam with severe skin involvement. which lack a single diagnostic procedure [15] and are characterized by the coexistence of diagnostic features from different entities [16].

While the underlying immunopathogenic mechanisms are still not completely understood, drug presentation by class I human leukocyte antigen (HLA) molecules and subsequent activation and clonal expansion of CD8+ $\mathrm{T}$ cells seem to be necessary for immunological responses to be triggered [6]. Concerning SJS and TEN, besides playing an important role in the initiation phase $[17,18]$, cytotoxic T lymphocytes also participate in the amplification of the immune response both by cell-cell contact (particularly Fas-Fas ligand interaction) and synthesis of cytolytic proteins and cytokines $[19,20]$. The Fas-Fas ligand interaction might not only mediate keratinocyte apoptosis but also promote inflammation via NF- $\kappa B$ activation [20]. Additionally, cytotoxic proteins, such as perforin/granzyme B and granulysin (produced not only by cytotoxic $\mathrm{T}$ lymphocytes but also by natural killer cells) also contribute to keratinocyte apoptosis $[19,20]$. Finally, several cytokines, including TNF- $\alpha$ and IL- 6 , have been ascribed a potential role in the pathogenesis of SJS and TEN $[19,21]$.

Certain HLA alleles have been associated with several DDAR. HLA molecules are highly polymorphic and are, therefore, involved in variable interactions with drug antigens [19]. Thus, an immunological response to certain drug antigens may be triggered in patients carrying specific HLA alleles, leading to T-cell activation and clonal expansion [19]. Drugs strongly associated with DDAR in the presence of particular HLA alleles include allopurinol, antiretrovirals (namely abacavir and nevirapine), aromatic amine anticonvulsants (in particular carbamazepine and phenytoin), and sulfonamides [10, 22, 23]. 


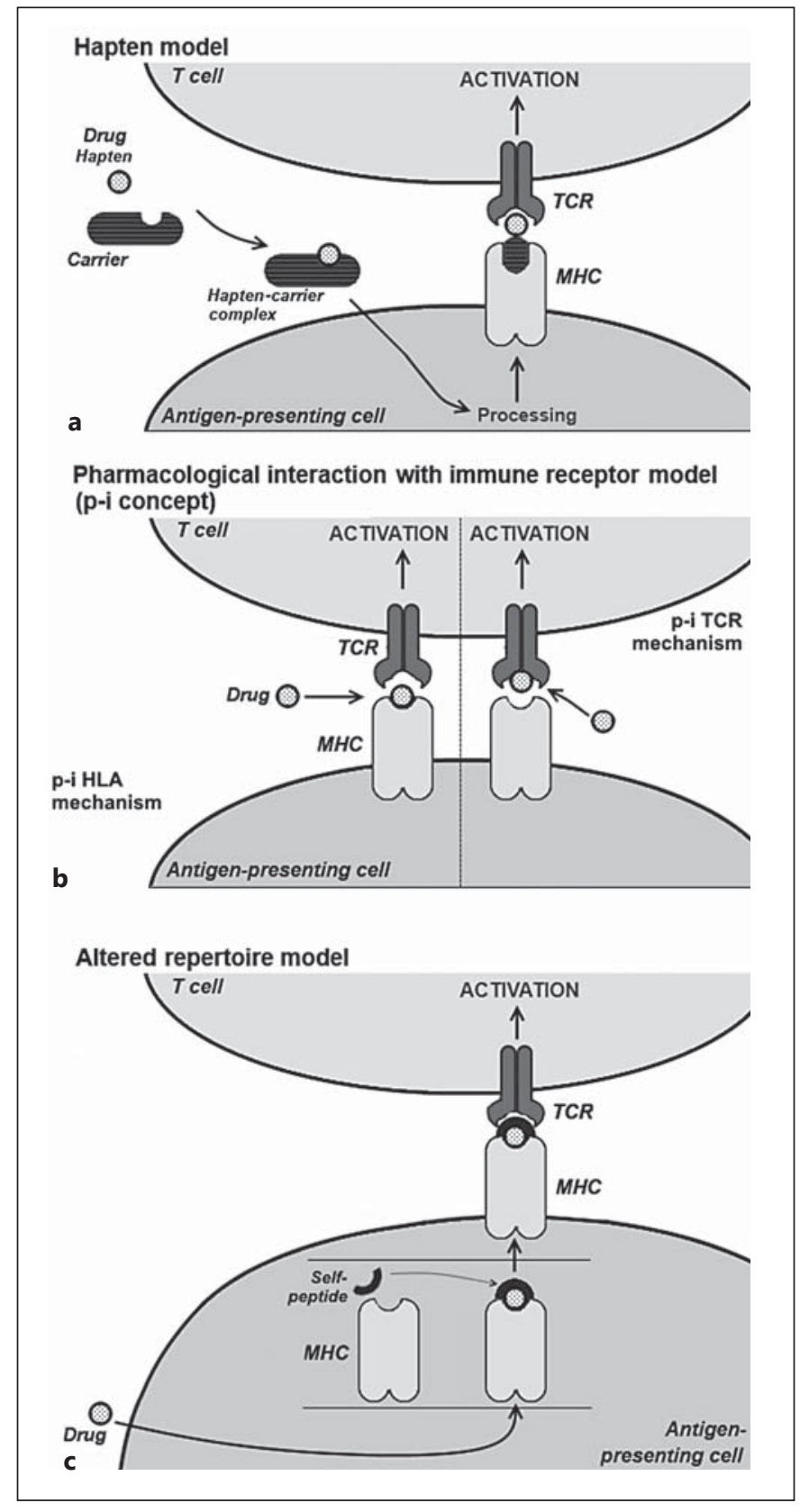

Fig. 2. Immunopathogenic models of DDAR. Three immunological models have attempted to explain the role of drug interactions with human MHC molecules (HLA) in the pathogenesis of DDAR. According to the hapten model (a), drugs bind to carriers, generating hapten-carrier complexes, which are subsequently processed by antigen-presenting cells. The processed complexes are then presented to the TCR bound to MHC molecules. According to the pharmacological interaction with the immune receptor model ( $\mathrm{p}-\mathrm{i}$ concept) (b), drugs bind directly to MHC molecules and/or TCR, activating $\mathrm{T}$ cells. Finally, the altered repertoire model (c) holds that drugs bind to $\mathrm{MHC}$ molecules, changing the repertoire of selfpeptides capable of binding to these molecules. In other words, some self-peptides become capable of binding to MHC molecules, inducing $\mathrm{T}$-cell activation.

\section{Immunological Models}

The immunopathogenesis of DDAR and their association with HLA alleles are currently explained by different immunological models (fig. 2), namely the hapten (and prohapten) model and the concept of direct pharmacological interaction with immune receptors ( $\mathrm{p}-\mathrm{i}$ concept). Nevertheless, some questions remain unexplained by these models, raising the hypothesis that viral infections may also play a major role in the immunopathogenesis of DDAR.

\section{The Hapten and Prohapten Model}

Haptens are small reactive molecules $(<1 \mathrm{kDa})$ incapable of inducing a specific immune response per se. However, haptens bind covalently to soluble or nonsoluble (membrane-bound) high-molecular-weight proteins (carriers), generating hapten-carrier complexes capable of triggering an immune response [24-26]. Prohaptens are nonreactive molecules and as such are incapable of binding to carriers. However, in the liver, prohaptens can be metabolized into haptens, which are capable of binding to carriers and generating hapten-carrier complexes [27]. Metabolism of prohaptens in the liver does not necessarily trigger an immune response, as the liver maintains a tolerogenic environment $[27,28]$. However, hepatitis can develop whenever a reactive compound leaves the liver, or whenever the immune response to that compound occurs in lymph nodes near the liver [29].

In order to induce a $\mathrm{T}$-cell response, immunogenic hapten-carrier complexes need to activate the innate immune system (in contrast to what is described for the $\mathrm{p}-\mathrm{i}$ concept) - for example, sulfamethoxazole activates dendritic cells after being converted into its nitroso metabolite, while imiquimod activates dendritic cells by binding to Toll-like receptor $7[25,27,30]$. Processed haptenated peptides are then presented by activated antigen-presenting cells bound to major histocompatibility (MHC) molecules. These latter molecules, in turn, present these peptides to naïve $T$ cells, causing their activation and triggering an immune response in the lymph nodes [24, 25]. Re-exposure to a hapten to which a patient is already sensitized triggers an inflammatory response with memory T-cell proliferation within 24-72 h [25]; effector T cells (including effector memory $\mathrm{T}$ cells) subsequently migrate to the site at which the hapten-carrier complexes were generated during the initial exposure, unlike central memory $\mathrm{T}$ cells (as well as naïve T cells), which, on expo- 
sure to a hapten-carrier complex, migrate to lymph nodes $[24,26]$. Thus, activation of effector T cells results in local responses at the site where hapten-carrier complexes were initially generated and presented, while stimulation of central memory $\mathrm{T}$ cells is associated with lymph node involvement [26].

Therefore, the hapten/prohapten model does not convincingly explain why re-exposure to systemically administered drugs often results in allergic reactions with predominant cutaneous manifestations but no significant lymph node involvement $[24,26]$. Moreover, neither the hapten nor the prohapten model explains why several drugs (such as penicillin) induce hapten formation and activate the innate immune system, but are only associated with DDAR in a minority of exposed patients [25, 30].

\section{The Pharmacological Interaction with the Immune Receptor Model (p-i Concept)}

The p-i concept claims that drugs induce DDAR without binding to a carrier and without forming a haptencarrier complex [27, 31, 32]. This model therefore posits that a drug can directly stimulate T cells and, consequently, generate a specific immune response without needing to be previously processed or metabolized $[27,31,32]$.

According to this model, drugs reversibly and noncovalently bind to MHC molecules or T-cell receptors (TCR), strengthening the affinity between MHC-peptide complexes and the respective TCR $[26,31,32]$. Thus, by directly interacting with MHC molecules ( $\mathrm{p}$-i HLA mechanisms), these drugs would form a complex that triggers a strong immune response mediated by T cells [32]. After binding directly to $\mathrm{MHC}$ molecules, drugs might also promote a modification in the repertoire of HLA ligands capable of binding and being presented to T cells [32]. This specific mechanism was elegantly described for abacavir DDAR, being sometimes termed 'altered repertoire model'. In fact, abacavir appears to pass from the extracellular milieu to the cell endoplasmic reticulum and binds noncovalently to specific residues in the F pocket of the HLAB*57:01 peptide-binding cleft, modifying the repertoire of self-peptide ligands capable of binding and being presented to T cells; this alteration would allow peptides that do not usually bind to MHC to be presented to T cells, inducing a polyclonal primary immune response $[33,34]$.

Alternatively, other drugs might directly bind to TCR ( $\mathrm{p}-\mathrm{i}$ TCR mechanisms), either directly stimulating the TCR or altering the TCR and subsequently promoting an increased reactivity to particular HLA-peptide complexes [32].

Therefore, activation of tissue memory $\mathrm{T}$ cells as described by the p-i concept adequately explains the development of generalized or predominantly cutaneous manifestations upon drug reexposure (most effector memory T cells, which have a low activation threshold, appear to be located in the skin) $[26,35]$. In cases where DDAR develop without an apparent previous sensitization phase (i.e., when the patient first comes into contact with the drug) [27], it is believed that the effector response (occurring according to the $\mathrm{p}-\mathrm{i}$ concept) is mounted following cross-reaction to other peptides, including viral antigens (vide infra).

\section{Role of Viral Infections}

Several epidemiological studies have found viral infections to be associated with DDAR. Human herpes virus (HHV) 6 activation, for example, is associated with carbamazepine-induced DRESS [36], while several cases of HHV reactivation have been described in association with allopurinol DDAR [37, 38]. Furthermore, EpsteinBarr and cytomegalovirus reactivations have been observed in the context of different SCAR [39]. Such observations have prompted researchers to investigate whether viral infections, and HHV infections in particular, might participate in the immunopathogenesis of DDAR.

The heterologous immunity model put forward by White et al. [4] posits that $\mathrm{T}$ cells participating in DDAR partially consist of effector memory $\mathrm{T}$ cells previously formed in response to HHV infections. Thus, T cells reactive against HHV would cross-react with specific HLAdrug complexes, triggering an immune response. According to this model, the different clinical phenotypes of distinct drug-induced adverse reactions (e.g., the predominantly mucocutaneous manifestations associated with HLA-B*15:02-restricted carbamazepine-induced DDAR versus the mainly systemic symptoms of HLAB*57:01-related abacavir DDAR) would be explained by activation of T cells primed to different HHV types [4]. Additionally, the heterologous immunity model might explain why some DDAR are associated with relatively rapid development of symptoms (effector memory cell activation requires minimal costimulatory signals), and why certain drug-specific T-cell responses persist for years after drug exposure and withdrawal [4].

HIV might also play a role in the immunopathogenesis of some DDAR and, in fact, HIV-positive patients are 
particularly predisposed to CD8+-mediated allergy reactions, in particular to toxic epidermal necrolysis, evidenced by a higher incidence and mortality in these patients $[6,11,40]$. The discovery of HIV antigens in the skin lesions of SCAR patients led to the suggestion that these might be drug-enhanced cytotoxic reactions to viral cutaneous antigens [41].

\section{Specific DDAR and HLA Alleles}

Several associations between specific HLA alleles and DDAR have been described (listed in table 1). However, the best-studied associations, both epidemiologically and immunologically, involve abacavir, nevirapine, carbamazepine, and allopurinol. These associations are described in greater detail below.

\section{Abacavir}

Abacavir is an antiretroviral of the reverse transcriptase inhibitor class. Nearly $5 \%$ of patients exposed to this drug develop a drug hypersensitivity syndrome characterized by two or more of the following symptoms: malaise, rash, fever, lethargy, gastrointestinal symptoms (nausea, vomiting, and abdominal pain), and respiratory symptoms (cough and dyspnea) [42, 43]. These symptoms tend to appear within the first days or weeks of therapy and disappear after withdrawal $[42,43]$. Rechallenge with abacavir is potentially fatal, with symptoms reappearing within hours.

Several studies have shown that abacavir DDAR is more common in HLA-B*57:01 carriers [44-46]. Nevertheless, the sole presence of this allele does not seem sufficient to trigger abacavir DDAR, since not all HLA$B * 57: 01$ carriers develop this reaction [33]. The association between abacavir DDAR and HLA-B*57:01 expression has been studied for several populations and ethnicities, including Caucasians, Afro-Americans, Thais, and Hispanics [45, 47, 48]. While early studies reported HLA$B * 57: 01$ carriage to be a poor predictor of abacavir DDAR in Afro-Americans, current evidence suggests that HLA$B^{*} 57: 01$ expression is strongly associated with abacavir DDAR in both Caucasians and Africans/Afro-Americans, indicating that the apparent lower sensitivity of HLA-B*57:01 was probably due to a high rate of false positives (namely in patients who were diagnosed with abacavir DDAR solely based on their clinical symptoms) in populations with a low prevalence of the allele $[45,48]$.
Before initiating therapy with abacavir, patients should be tested for the HLA-B*57:01 allele. According to several studies conducted in Caucasians, genotyping for HLA-B* 57:01 is highly cost-effective, and has high specificity and sensitivity; as previously mentioned, the initial evidence of low sensitivity was obtained from studies where abacavir DDAR was not diagnosed by epicutaneous tests but by clinical criteria only [48-50].

Abacavir DDAR is immunologically mediated, as evidenced by the presence of cytotoxic T cells in the cutaneous lesions of patients developing rash [51]. According to the most widely accepted hypothesis, abacavir (but not its metabolites) binds noncovalently to the bottom of the MHC antigen-binding cleft, modifying the shape and structure of the F pocket, and thereby inducing a preference for smaller amino-acid residues (valine, isoleucine, or leucine) $[33,34]$. Abacavir thus alters the repertoire of peptides that are able to bind to MHC, allowing for presentation of novel self-peptides, which in the absence of abacavir would not bind to HLA-B*57:01 (this mechanism is sometimes termed 'altered repertoire model'; vide supra [34]). As these peptides are perceived as foreign by $\mathrm{T}$ cells, a cytotoxic response is triggered [33]. Abacavir restriction to HLA-B*57:01 is thus explained by the sensitivity of abacavir to the F pocket of HLA-B*57:01, namely to its $\operatorname{Ser}^{116}$ residue [34]. The absence of this residue in similar allotypes $(* 57: 11, * 58: 01$, and $* 57: 03)$ would explain their lack of association with abacavir DDAR [34].

A complementary study of abacavir DDAR by Adam et al. [52] found that $\mathrm{T}$-cell reactivity is determined by TCR avidity, with in vitro T-cell activation being influenced by MHC molecule density on the cell surface, as well as drug dose and abacavir pulsing duration. In addition, another study showed that costimulatory signs are not needed for primary activation of abacavir-reacting $\mathrm{T}$ cells, suggesting that these cells partly originate from memory $\mathrm{T}$ cells [53]. Finally, according to Lucas et al. [54], these memory T cells might have been formed after early exposure to other exogenous antigens cross-reacting with abacavir-HLA-B*57:01-endogenous peptide ligand complexes.

\section{Nevirapine}

Nevirapine is an antiretroviral of the class of non-nucleoside reverse transcriptase inhibitors; it acts by binding to a hydrophobic cleft of the viral reverse transcriptase, disrupting its normal activity [47]. Eight to $16 \%$ of patients exposed to nevirapine develop DDAR, which can 
range from a simple cutaneous reaction to hepatitis [5557]. These reactions mostly occur during the first 18 weeks of treatment [55]. Nevertheless, only a minority of patients develop potentially life-threatening conditions, such as SJS or TEN $[57,58]$. As occurs with abacavir, rechallenge with nevirapine is associated with allergy reactions characterized by greater severity and a decreased lag period $[57,59]$.

Several studies have found nevirapine DDAR to be associated with distinct specific MHC I and MHC II alleles. In Caucasians, for example, HLA-DRB ${ }^{*} 01: 01$ expression has been linked to rash, fever, and hepatitis [60], while in an Australian study, HLA-B*35:01 expression has been linked to rash [61]. HLA-B*35 was also identified as a risk factor for nevirapine-induced DDAR in Caucasians, Thais, and Indians $[56,62]$. Other alleles described in association with nevirapine-induced allergy/DRESS include HLA-C*04 (in Caucasians, Afro-Americans, Africans, and Han Chinese) [56, 63], HLA-C*08 (in Caucasians and Japanese) [64], and the haplotype HLA-C*08-B14 (in Italians) [65]. As several HLA alleles have been described to be associated with nevirapine DDAR, genetic screening for this condition might be difficult to implement [56].

Nevirapine DDAR appears to be mediated both by CD8+ and CD4+ T cells (which can explain its association with both MHC class I and II molecules) $[22,66]$, and adverse reactions are more common and more severe in immunologically uncompromised patients undergoing HIV postexposure prophylaxis [67]. The risk of severe allergy is higher among patients with a CD4+ count $>250$ cells/ $\mu \mathrm{l}$ (for females) or $>400$ cells/ $\mu \mathrm{l}$ (for males). Nevirapine should, therefore, not be prescribed in these patients [55].

Concerning the immunopathogenesis of nevirapine DDAR, 12-OH-NVP and other reactive metabolites formed during biotransformation phase I reactions act as haptens, which, unlike nevirapine, are able to bind a carrier protein and, therefore, trigger an immune response [67]. Although the specific mechanism of drug-HLA interaction largely remains to be discovered, it is known that 12-OH-NVP formation is influenced by the patient's genotype [63]. Moreover, unlike drug exposure, both gender and CD4+ T-cell levels are known to be risk factors for nevirapine DDAR [63]. It has also been suggested that genes outside the HLA complex [namely noncodifying single nucleotide polymorphisms (SNP) within the CCHCR1 gene] might play an additional role in the development of particular DDAR phenotypes [68]. This could possibly explain the large diversity of genotypes in patients who develop nevirapine DDAR.

HLA and Drug Hypersensitivity

\section{Carbamazepine}

Carbamazepine is an aromatic anticonvulsant mainly used in the treatment of epilepsy, bipolar disorder, and trigeminal neuralgia [69]. It has been associated with DRESS and SCAR occurring 2-8 weeks after treatment initiation [69]. These reactions are rare in Europeans (1-6 cases per 10,000 exposed patients) but almost 10 times more common in Han Chinese [22].

Many HLA alleles associated with carbamazepine-induced SCAR have been identified, and the strongest associations have been reported for HLA-B*15:02 and HLA$A^{*} 31: 01$ [70]. Carriers of these alleles are mainly of South Asian ancestry. In fact, the association between HLA-B*15: 02 and the development of carbamazepine-induced SJS was first described among Han Chinese [71]. Several other studies have provided evidence to strengthen this association, which has been found in other Asian ethnicities such as Thai, Korean, Malay, and Indian populations, but not Japanese [70]. In a European case-control study including 12 carbamazepine-induced SJS/TEN cases, however, only 4 patients (all of Asian ancestry) were HLA-B*15:02 positive [72]. Therefore, this allele cannot be considered a universal marker for carbamazepine-induced SJS.

On the other hand, the HLA-A*31:01 allele has been described as a predictor of carbamazepine-induced DDAR in Northern European [73] and Japanese [74] patients. However, a subsequent meta-analysis found that HLA-A*31:01 expression was associated only with carbamazepine-induced DRESS (in Chinese and European individuals) not with carbamazepine-induced SCAR [75].

Protective HLA alleles (such as HLA-B*40:01 and HLA-A*24:02) against the development of carbamazepine cutaneous DDAR have also been identified, particularly in Asian populations [70]. It is still unknown, however, whether these alleles exert a true protective effect or simply appear to be more frequent in the general population than in SJS/TEN cases [70, 76].

Concerning genetic screening, in the case of HLA$B^{*} 15: 02$, a retrospective study performed in Thailand concluded that screening for this allele is less costly than treating carbamazepine-induced SJS cases [77]. However, according to the US Food and Drug Administration, screening for HLA-B*15:02 is only recommended for patients of Asian ancestry, since this allele is mainly expressed in those individuals [62]. On the contrary, although not routinely performed, screening for HLAA*31:01 before carbamazepine prescription might prove cost-effective in some European countries, as the results of one British study suggested [78].

Int Arch Allergy Immunol 2016;170:163-179 171 
According to Wei et al. [79], carbamazepine does not require intracellular metabolism or antigenic processing prior to HLA-B*15:02 binding. The authors also reported the existence of key residues in the HLA-B*15:02 peptidebinding groove ( $\mathrm{Ile}^{95}$, $\mathrm{Leu}^{156}$, and, in particular, Asn ${ }^{63}$ ) that are required for carbamazepine presentation and T-cell activation. Nevertheless, this study does not exclude the possibility that carbamazepine metabolites irreversibly bound to HLA-B*15:02 peptides might also play a role in triggering an immunological response [79]. Another possibility is that the role of HLA-B*15:02 in the immunopathogenesis of carbamazepine DDAR involves the modification of the peptides which are capable to bind HLA-B*15:02, allowing for the presentation of self-peptides [34].

A specific TCR clonotype - V $\beta$-11-ISGSY - has also been found to be present in $84 \%$ of patients with carbamazepine-induced SCAR, but absent in carbamazepinetolerant individuals [80]. Thus, the pathogenesis of adverse drug reactions to carbamazepine appears to involve both a specific HLA allotype and a TCR clonotype [4].

\section{Allopurinol}

Allopurinol, a xanthine oxidase inhibitor that blocks uric acid production, is used for the treatment of chronic gout, hyperuricemia secondary to tumor lysis syndrome, and uric acid nephrolithiasis [81, 82]. Approximately 5\% of patients exposed to allopurinol develop a DDAR, with manifestations ranging from mild rash to life-threatening conditions such as SJS and TEN, potentially accompanied by fever, hepatic dysfunction and kidney failure [82].

In 2005, a case-control study performed in Han Chinese found HLA-B*58:01 expression to be strongly associated with the development of allopurinol-induced SCAR [83]. Similar results were obtained in studies of other Asian populations, namely Thais, Japanese, and Koreans [84-86]. A significant, albeit weaker, association was also found in European patients [81]. A study by Lonjou et al. [87] found HLA-B*58:01 to be expressed in only $55 \%$ of patients with allopurinol-induced SJS/TEN, while a study by Gonçalo et al. [88] in Portuguese patients found the same allele to be present in $64 \%$ of patients with allopurinol-induced SJS/TEN and DRESS. The weaker association reported in Europeans might be due to differences in HLA-B*58:01 carriage rates $-20 \%$ of Han Chinese carry this allele compared with $<6 \%$ of Caucasians [81]. Thus, screening for HLA-B*58:01 appears to be cost-effective in some Asian populations and in patients with advanced renal failure (vide infra) $[4,89,90]$.
HLA-B*58:01 carriage is thus an important risk factor for the development of allopurinol-induced SCAR. According to one systematic review, allergy risk is $80-97$ times higher in patients expressing this allele [91]. Nevertheless, HLA-B*58:01 expression is not sufficient to explain the occurrence of allopurinol DDAR [87], and, in fact, other risk alleles have been identified. One genomewide association study conducted in European patients found 6 SNP to be associated with allopurinol-induced SJS/TEN [92]. The authors of the study also reported that carriers of the HLA-B*58 allele had a higher frequency of the haplotype CACGAC, which is formed by the risk allele of each of the $6 \mathrm{SNP}$ [92]. The authors concluded that there is incomplete linkage disequilibrium between CACGAC and the HLA-B*58 allele and hypothesized that the main genetic determinants of allopurinol DDAR might not be the HLA-B alleles but rather some loci in linkage disequilibrium with these alleles. Finally, a Korean casecontrol study found that, compared with controls, patients with allopurinol-induced SCAR had a higher frequency of HLA-Cw*03:02 and HLA-A*33:03 but a lower frequency of HLA-A*02:01 [86]. Besides gout, allopurinol is also widely used for preventing hyperuricemia secondary to tumor lysis syndrome in patients with hematological neoplasms prior to starting chemotherapy [93]. However, the maculopapular eruptions recorded in this setting do not appear to be associated with HLA-B*58:01 expression but rather with the presence of HLA-DR9 and HLA-DR14 alleles [93].

Concerning the immunopathogenic mechanisms, as allopurinol is rapidly converted to oxypurinol by xanthine oxidase, recent studies have suggested that allopurinol DDAR might be mediated by both $\mathrm{T}$ cells reacting to allopurinol and $\mathrm{T}$ cells reacting to oxypurinol (fig. 3) [94]. T cells reacting to oxypurinol would appear to play a more important role, as this compound has a longer half-life and appears to bind more strongly to HLAB*58:01 than allopurinol $[94,95]$. Additionally, T cells reacting to oxypurinol are more restricted by HLA-B* 58 : 01 for their activation [95].

Allopurinol and oxypurinol appear to activate a polyclonal effector $\mathrm{T}$-cell response after binding directly to HLA-B*58:01 [95]. In fact, allopurinol and oxypurinol bind to HLA when its drug binding site is exposed (something which happens only transiently), 'forcing' a change of conformation in previously HLA-bound endogenous peptides. This new conformation is perceived as 'foreign' by $\mathrm{T}$ cells and triggers an immune response [95].

Activation of T cells reactive to allopurinol and oxypurinol occurs in a dose-dependent manner, and, therefore, 


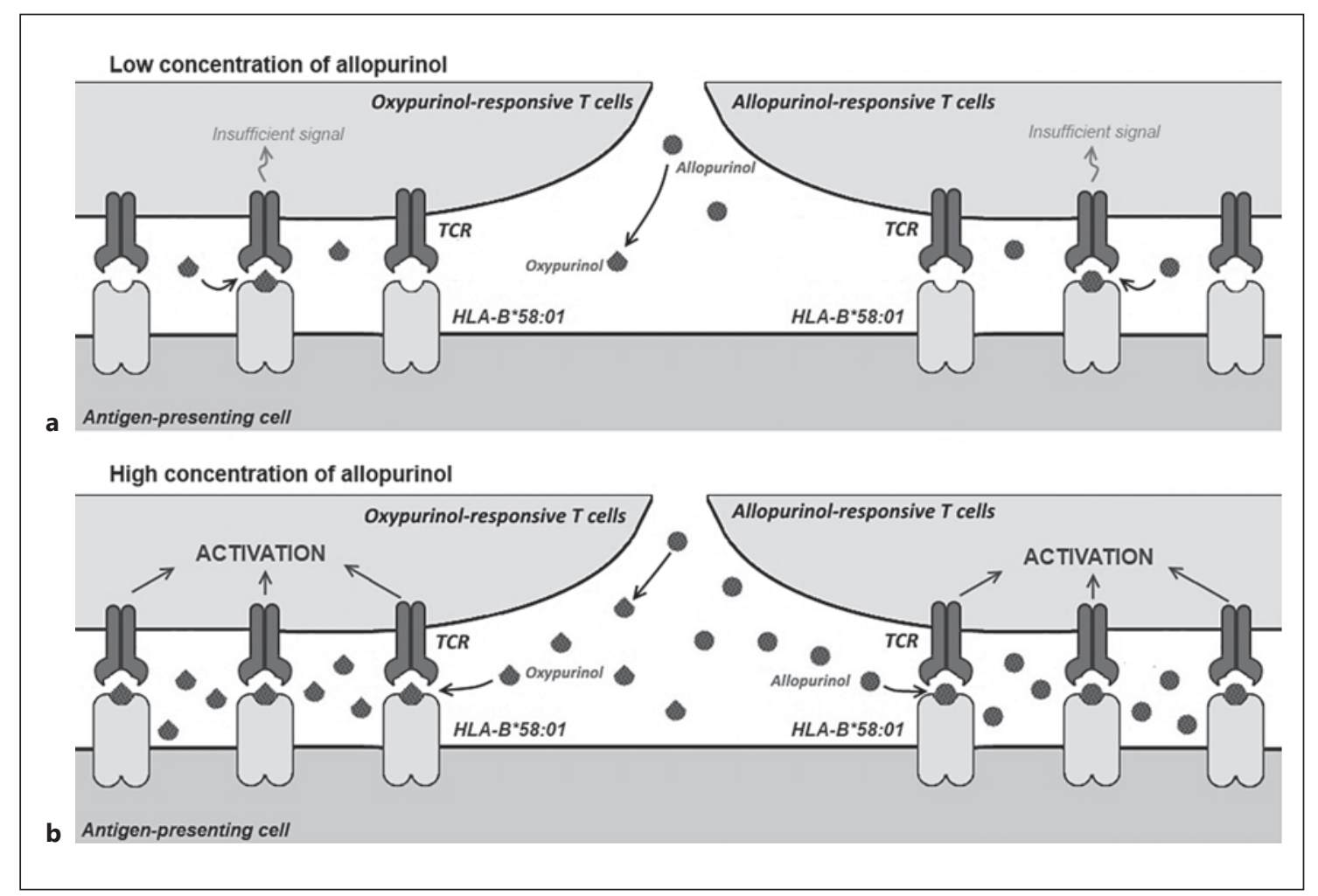

Fig. 3. Immunopathogenic mechanism underlying allopurinol DDAR. Allopurinol is extensively converted to oxypurinol by xanthine oxidase, with both molecules interacting with the HLA-B*58: 01 allele. Low levels of allopurinol and oxypurinol (a) are incapable

higher doses of these compounds are associated with a higher risk of SJS/TEN [94, 96]. In fact, a higher starting dose of allopurinol has been identified as a risk factor for allopurinol DDAR [94]. Renal insufficiency, which is associated with impaired renal clearance and thus higher plasma levels of oxypurinol, is also considered a risk factor for allopurinol-induced SCAR $[94,97]$. Moreover, renal insufficiency is associated with a poor prognosis, correlating with higher mortality and prolonged cutaneous reactions [97]. This evidence contests the dogma that type $B$ adverse reactions are totally unpredictable and dose independent, thus opening the possibility for their prevention by desensitization techniques [94, 98]. In fact, no SCAR episodes were observed after Jung et al. [98] treated a sample of patients with a high risk of allopurinolinduced SCAR (HLA-B*58:01+ carriers with chronic kidney disease) to a tolerance induction protocol consisting of a gradual increase in allopurinol dose [98]. As previously mentioned, viral infections also appear to increase the risk of allopurinol-induced DDAR $[37,38]$.

HLA and Drug Hypersensitivity of generating a sufficiently strong signal to the TCR for cell activation. By contrast, high levels of allopurinol and oxypurinol (b) (as recorded in patients with chronic kidney disease) allow for T-cell activation.

\section{Genetic Screening}

Screening for alleles associated with drug-induced hypersensitivity can prevent the onset of these reactions. However, pharmacogenetic screening should be reserved for alleles whose association with DDAR is strongly supported by scientific evidence [99]. Additionally, the tests must be cost-effective and have high sensitivity, specificity, and predictive values (ideally, the negative predictive value should be $100 \%$ to ensure drug safety). Thus, the decision to implement a screening test should also be guided by the target population and the respective prevalence of the alleles being evaluated [22, 99].

There are several methods for identifying HLA-specific alleles. Genomic DNA sequencing-based typing, which is based on the Sanger method, is one of the most common methods, and is the gold standard for HLA-B*57:01 identification [100-102]. However, this method is expensive, not always available, and can yield ambiguous results $[100,101,103]$. Other methods include sequence-specific 
primer PCR and real-time PCR coupled with melting curve analysis. Although once popular, sequence-specific primer PCR can also generate ambiguous results and requires constant sequence updates [101, 103]. Real-time PCR, by contrast, is less prone to ambiguity and is highly specific, sensitive, and efficient [100].

Instead of screening for HLA alleles by sequencingbased typing or PCR, some laboratories opt for detecting SNP in linkage disequilibrium with the respective alleles. In Caucasians and Hispanics, the SNP rs2395029 is in linkage disequilibrium with HLA-B*57:01 [104]. Detection of rs 2395029 is associated with a sensitivity of $100 \%$ and a specificity of $99 \%$ for the identification of HLAB*57:01 carriers. However, despite this strong association, this disequilibrium is incomplete, and, in fact, detection of rs2395029 is associated with a positive predictive value $<100 \%$ [104]. Based on the results of a Japanese study, rs9263726 (an SNP located within the PSORS1C1 gene) is in complete linkage disequilibrium with the HLA-B*58:01 allele [105], leading the authors to conclude that rs9263726 detection can be effectively used to screen for HLA-B*58:01 carriage [105].

Detection of HLA-B*58:01 by loop-mediated isothermal amplification initially appeared to be a simple and rapid screening method, with high sensitivity and specificity. However, the higher risk of contamination and ambiguous results led the authors to recommend additional genotyping methods in the case of positive results [106]. Kostenko et al. [107] developed a monoclonal antibody that reacts against HLA-B*57:01 and HLA-B*58:01 proteins. However, while this antibody identifies HLAB*57:01 and HLA-B*58:01 carriers, it does not discriminate between them. It could, therefore, be used as a prescreening test to quickly identify low-risk patients (noncarriers) and start them on treatment with abacavir or allopurinol without the need for further tests [107]. Finally, according to De Spiegelaere et al. [102], despite its low specificity, flow-cytometric investigation of the HLA$B * 57: 01$ allele is a highly sensitive technique that would substantially decrease the number of genetic tests required.

\section{Conclusion}

DDAR are potentially fatal and hence represent a major health problem. As more and more drugs are becoming available, it is essential to study the immunogenetic mechanisms underlying DDAR. This characterization will enable the formulation of adequate strategies to pre-

vent and treat these reactions. In fact, genetic screening is already a reality for abacavir and carbamazepine, and will help to prevent the development of DDAR in carriers of risk alleles.

Increasing evidence shows the crucial role played by HLA in DDAR. Despite the number of already known interactions between certain drugs and HLA alleles, much remains to be learned. Indeed, only a small number of HLA-drug interactions have been identified, and genetic screening is only routinely applied to an even smaller number of drugs, reminding that there is still a long way to go from bench to bedside. Furthermore, for many HLA alleles, the association with DDAR has only been established by epidemiological studies. However, understanding the underlying immunological mechanisms is of the utmost importance, as they can explain the symptoms and provide the basis for designing new treatment strategies. Nevertheless, HLA-drug interactions do not totally explain the development of DDAR. These reactions are multifactorial, and several polymorphisms and environmental factors might contribute to their onset. Characterization of these factors has only recently begun, and much information is still missing.

In conclusion, HLA alleles are intricately involved in DDAR. Understanding these interactions is essential for ensuring the administration of drugs with the best efficacy/safety profile. In fact, good clinical practice requires not only practical knowledge but also a solid theoretical basis.

\section{Disclosure Statement}

The authors declare that they have no conflict of interest.

\section{References} epidemiology of hypersensitivity drug reactions. Immunol Allergy Clin North Am 2004; 24:345-356.

2 Knowles SR, Uetrecht J, Shear NH: Idiosyncratic drug reactions: the reactive metabolite syndromes. Lancet 2000;356:1587-1591.

3 Torres MJ, Mayorga C, Blanca M: Nonimmediate allergic reactions induced by drugs: pathogenesis and diagnostic tests. J Investig Allergol Clin Immunol 2009;19:80-90.

4 White KD, Chung WH, Hung SI, Mallal S, Phillips EJ: Evolving models of the immunopathogenesis of $\mathrm{T}$ cell-mediated drug allergy: the role of host, pathogens, and drug response. J Allergy Clin Immunol 2015;136: 219-234. 
5 Johansson SG, Bieber T, Dahl R, Friedmann PS, Lanier BQ, Lockey RF, Motala C, Ortega Martell JA, Platts-Mills TA, Ring J, Thien F, Van Cauwenberge P, Williams HC: Revised nomenclature for allergy for global use: report of the nomenclature review committee of the World Allergy Organization, October 2003. J Allergy Clin Immunol 2004;113:832-836.

6 Harr T, French LE: Toxic epidermal necrolysis and Stevens-Johnson syndrome. Orphanet J Rare Dis 2010;5:39.

7 Fisher K, Vuppalanchi R, Saxena R: Drug-induced liver injury. Arch Pathol Lab Med 2015; 139:876-887.

8 Bastuji-Garin S, Rzany B, Stern RS, Shear NH, Naldi L, Roujeau JC: Clinical classification of cases of toxic epidermal necrolysis, StevensJohnson syndrome, and erythema multiforme. Arch Dermatol 1993;129:92-96.

9 French LE: Toxic epidermal necrolysis and Stevens Johnson syndrome: our current understanding. Allergol Int 2006;55:9-16.

10 Borchers AT, Lee JL, Naguwa SM, Cheema GS, Gershwin ME: Stevens-Johnson syndrome and toxic epidermal necrolysis. Autoimmun Rev 2008;7:598-605.

11 Roujeau JC, Kelly JP, Naldi L, Rzany B, Stern RS, Anderson T, Auquier A, Bastuji-Garin S, Correia O, Locati F, et al: Medication use and the risk of Stevens-Johnson syndrome or toxic epidermal necrolysis. N Engl J Med 1995; 333:1600-1607.

12 Auquier-Dunant A, Mockenhaupt M, Naldi L, Correia O, Schroder W, Roujeau JC, SCAR Study Group. Severe Cutaneous Adverse Reactions: Correlations between clinical patterns and causes of erythema multiforme majus, Stevens-Johnson syndrome, and toxic epidermal necrolysis: results of an international prospective study. Arch Dermatol 2002;138:1019-1024.

13 Shiohara T, Iijima M, Ikezawa Z, Hashimoto $\mathrm{K}$ : The diagnosis of a DRESS syndrome has been sufficiently established on the basis of typical clinical features and viral reactivations. Br J Dermatol 2007;156:1083-1084.

14 Kardaun SH, Sidoroff A, Valeyrie-Allanore L, Halevy S, Davidovici BB, Mockenhaupt M, Roujeau JC: Variability in the clinical pattern of cutaneous side-effects of drugs with systemic symptoms: does a DRESS syndrome really exist? Br J Dermatol 2007;156:609-611.

15 Schnyder B, Pichler WJ: Nonimmediate drug allergy: diagnostic benefit of skin testing and practical approach. J Allergy Clin Immunol 2012;129:1170-1171.

16 Bouvresse S, Valeyrie-Allanore L, Ortonne N, Konstantinou MP, Kardaun SH, Bagot M, Wolkenstein P, Roujeau JC: Toxic epidermal necrolysis, DRESS, AGEP: do overlap cases exist? Orphanet J Rare Dis 2012;7:72.

17 Correia O, Delgado L, Ramos JP, Resende C, Torrinha JA: Cutaneous T-cell recruitment in toxic epidermal necrolysis. Further evidence of CD8+ lymphocyte involvement. Arch Dermatol 1993;129:466-468.
18 Correia O, Delgado L, Roujeau JC, Le Cleach L, Fleming-Torrinha JA: Soluble interleukin 2 receptor and interleukin $1 \alpha$ in toxic epidermal necrolysis: a comparative analysis of serum and blister fluid samples. Arch Dermatol 2002;138:29-32.

19 Chung WH, Hung SI: Recent advances in the genetics and immunology of Stevens-Johnson syndrome and toxic epidermal necrosis. J Dermatol Sci 2012;66:190-196.

20 Su SC, Chung WH: Cytotoxic proteins and therapeutic targets in severe cutaneous adverse reactions. Toxins 2014;6:194-210.

21 Correia O, Delgado L, Barbosa IL, Campilho $\mathrm{F}$, Fleming-Torrinha J: Increased interleukin 10 , tumor necrosis factor $\alpha$, and interleukin 6 levels in blister fluid of toxic epidermal necrolysis. J Am Acad Dermatol 2002;47:5862.

22 Phillips EJ, Mallal SA: Pharmacogenetics of drug hypersensitivity. Pharmacogenomics 2010;11:973-987.

23 Yang MS, Kang MG, Jung JW, Song WJ, Kang HR, Cho SH, Min KU: Clinical features and prognostic factors in severe cutaneous drug reactions. Int Arch Allergy Immunol 2013; 162:346-354

24 Schnyder B, Pichler WJ: Mechanisms of druginduced allergy. Mayo Clin Proc 2009;84: 268-272.

25 Adam J, Pichler WJ, Yerly D: Delayed drug hypersensitivity: models of T-cell stimulation. Br J Clin Pharmacol 2011;71:701-707.

26 Schnyder B, Brockow K: Pathogenesis of drug allergy - current concepts and recent insights. Clin Exp Allergy 2015;45:1376-1383.

27 Pichler WJ, Beeler A, Keller M, Lerch M, Posadas S, Schmid D, Spanou Z, Zawodniak A, Gerber B: Pharmacological interaction of drugs with immune receptors: the p-i concept. Allergol Int 2006;55:17-25.

28 Crispe IN: Hepatic T cells and liver tolerance. Nat Rev Immunol 2003;3:51-62.

29 Bowen DG, Zen M, Holz L, Davis T, McCaughan GW, Bertolino P: The site of primary T cell activation is a determinant of the balance between intrahepatic tolerance and immunity. J Clin Invest 2004;114:701-712.

30 Yun J, Adam J, Yerly D, Pichler WJ: Human leukocyte antigens (HLA) associated drug hypersensitivity: consequences of drug binding to HLA. Allergy 2012;67:1338-1346.

31 Pichler WJ: Pharmacological interaction of drugs with antigen-specific immune receptors: the p-i concept. Curr Opin Allergy Clin Immunol 2002;2:301-305.

32 Pichler WJ, Adam J, Watkins S, Wuillemin N, Yun J, Yerly D: Drug hypersensitivity: how drugs stimulate $\mathrm{T}$ cells via pharmacological interaction with immune receptors. Int Arch Allergy Immunol 2015;168:13-24.
33 Ostrov DA, Grant BJ, Pompeu YA, Sidney J, Harndahl M, Southwood S, Oseroff C, Lu S, Jakoncic J, de Oliveira CA, Yang L, Mei H, Shi L, Shabanowitz J, English AM, Wriston A, Lucas A, Phillips E, Mallal S, Grey HM, Sette A, Hunt DF, Buus S, Peters B: Drug hypersensitivity caused by alteration of the MHC-presented self-peptide repertoire. Proc Natl Acad Sci USA 2012;109:9959-9964.

34 Illing PT, Vivian JP, Dudek NL, Kostenko L, Chen Z, Bharadwaj M, Miles JJ, Kjer-Nielsen L, Gras S, Williamson NA, Burrows SR, Purcell AW, Rossjohn J, McCluskey J: Immune self-reactivity triggered by drug-modified HLA-peptide repertoire. Nature 2012;486: 554-558.

35 Pichler WJ, Daubner B, Kawabata T: Drug hypersensitivity: flare-up reactions, cross-reactivity and multiple drug hypersensitivity. J Dermatol 2011;38:216-221.

36 Aihara Y, Ito SI, Kobayashi Y, Yamakawa Y, Aihara M, Yokota S: Carbamazepine-induced hypersensitivity syndrome associated with transient hypogammaglobulinaemia and reactivation of human herpesvirus 6 infection demonstrated by real-time quantitative polymerase chain reaction. Br J Dermatol 2003; 149:165-169.

37 Hamaguchi Y, Fujimoto M, Enokido Y, Wayaku T, Kaji K, Echigo T, Takehara K: Intractable genital ulcers from herpes simplex virus reactivation in drug-induced hypersensitivity syndrome caused by allopurinol. Int J Dermatol 2010;49:700-704.

38 Watanabe Y, Matsukura S, Isoda Y, Morita A Aihara M, Kambara T: A case of toxic epidermal necrolysis induced by allopurinol with human herpesvirus- 6 reactivation. Acta Derm Venereol 2013;93:731-732.

39 Chen YC, Chiang HH, Cho YT, Chang CY, Chen KL, Yang CW, Lee YH, Chu CY: Human herpes virus reactivations and dynamic cytokine profiles in patients with cutaneous adverse drug reactions - a prospective comparative study. Allergy 2015;70:568-575.

40 Knight L, Muloiwa R, Dlamini S, Lehloenya RJ: Factors associated with increased mortality in a predominantly HIV-infected population with Stevens Johnson syndrome and toxic epidermal necrolysis. PLoS One 2014;9: e93543.

41 Correia O, Delgado L, Santos C, Miranda AM: HIV-1 in blister fluid of a patient with toxic epidermal necrolysis and AIDS. Lancet 1994; 344:1432-1433.

42 Martin MA, Kroetz DL: Abacavir pharmacogenetics - from initial reports to standard of care. Pharmacotherapy 2013;33:765-775.

43 Hetherington S, McGuirk S, Powell G, Cutrell A, Naderer O, Spreen B, Lafon S, Pearce G, Steel H: Hypersensitivity reactions during therapy with the nucleoside reverse transcriptase inhibitor abacavir. Clin Ther 2001;23: 1603-1614. 
44 Mallal S, Nolan D, Witt C, Masel G, Martin AM, Moore C, Sayer D, Castley A, Mamotte C, Maxwell D, James I, Christiansen FT: Association between presence of HLA-B*5701, HLA-DR7, and HLA-DQ3 and hypersensitivity to HIV-1 reverse-transcriptase inhibitor abacavir. Lancet 2002;359:727-732.

45 Saag M, Balu R, Phillips E, Brachman P, Martorell C, Burman W, Stancil B, Mosteller M, Brothers C, Wannamaker P, Hughes A, Sutherland-Phillips D, Mallal S, Shaefer M; Study of Hypersensitivity to Abacavir, Pharmacogenetic Evaluation Study Team: High sensitivity of human leukocyte antigenB*5701 as a marker for immunologically confirmed abacavir hypersensitivity in white and black patients. Clin Infect Dis 2008;46:11111118.

46 Mallal S, Phillips E, Carosi G, Molina JM, Workman C, Tomazic J, Jagel-Guedes E, Rugina S, Kozyrev O, Cid JF, Hay P, Nolan D, Hughes S, Hughes A, Ryan S, Fitch N, Thorborn D, Benbow A: HLA-B*5701 screening for hypersensitivity to abacavir. N Engl J Med 2008;358:568-579.

47 Decha P, Intharathep P, Udommaneethanakit T, Sompornpisut $\mathrm{P}$, Hannongbua $\mathrm{S}$, Wolschann P, Parasuk V: Theoretical studies on the molecular basis of HIV-1RT/NNRTIs interactions. J Enzyme Inhib Med Chem 2011;26:29-36.

48 Sousa-Pinto B, Pinto-Ramos J, Correia C, Goncalves-Costa G, Gomes L, Gil-Mata S, Araujo L, Delgado L: Pharmacogenetics of abacavir hypersensitivity: a systematic review and meta-analysis of the association with HLA-B*57:01. J Allergy Clin Immunol 2015; 136:1092.e3-1094.e3.

49 Zucman D, Truchis P, Majerholc C, Stegman S, Caillat-Zucman S: Prospective screening for human leukocyte antigen-B*5701 avoids abacavir hypersensitivity reaction in the ethnically mixed French HIV population. J Acquir Immune Defic Syndr 2007;45:1-3.

50 Wolf E, Blankenburg M, Bogner JR, Becker W, Gorriahn D, Mueller MC, Jaeger H, Welte R, Baudewig M, Walli R, Stoll M: Cost impact of prospective HLA-B*5701-screening prior to abacavir/lamivudine fixed dose combination use in Germany. Eur J Med Res 2010;15: 145-151.

51 Phillips EJ, Sullivan JR, Knowles SR, Shear $\mathrm{NH}$ : Utility of patch testing in patients with hypersensitivity syndromes associated with abacavir. AIDS 2002;16:2223-2225.

52 Adam J, Eriksson KK, Schnyder B, Fontana S, Pichler WJ, Yerly D: Avidity determines Tcell reactivity in abacavir hypersensitivity. Eur J Immunol 2012;42:1706-1716.

53 Adam J, Wuillemin N, Watkins S, Jamin H, Eriksson KK, Villiger P, Fontana S, Pichler WJ, Yerly D: Abacavir induced T cell reactivity from drug naive individuals shares features of allo-immune responses. PLoS One 2014;9:e95339.
54 Lucas A, Lucas M, Strhyn A, Keane NM, McKinnon E, Pavlos R, Moran EM, MeyerPannwitt V, Gaudieri S, D’Orsogna L, Kalams S, Ostrov DA, Buus S, Peters B, Mallal S, Phillips E: Abacavir-reactive memory $\mathrm{T}$ cells are present in drug naive individuals. PLoS One 2015; 10:e0117160.

55 Wit FW, Kesselring AM, Gras L, Richter C, van der Ende ME, Brinkman K, Lange JM, de Wolf F, Reiss P: Discontinuation of nevirapine because of hypersensitivity reactions in patients with prior treatment experience, compared with treatment-naive patients: the Athena Cohort Study. Clin Infect Dis 2008; 46:933-940.

56 Cornejo Castro EM, Carr DF, Jorgensen AL, Alfirevic A, Pirmohamed M: HLA-allelotype associations with nevirapine-induced hypersensitivity reactions and hepatotoxicity: a systematic review of the literature and metaanalysis. Pharmacogenet Genomics 2015;25: 186-198.

57 Pollard RB, Robinson P, Dransfield K: Safety profile of nevirapine, a nonnucleoside reverse transcriptase inhibitor for the treatment of human immunodeficiency virus infection. Clin Ther 1998;20:1071-1092.

58 Shubber Z, Calmy A, Andrieux-Meyer I, Vitoria M, Renaud-Thery F, Shaffer N, Hargreaves S, Mills EJ, Ford N: Adverse events associated with nevirapine and efavirenzbased first-line antiretroviral therapy: a systematic review and meta-analysis. AIDS 2013; 27:1403-1412.

59 Gangar M, Arias G, O’Brien JG, Kemper CA: Frequency of cutaneous reactions on rechallenge with nevirapine and delavirdine. Ann Pharmacother 2000;34:839-842.

60 Martin AM, Nolan D, James I, Cameron P, Keller J, Moore C, Phillips E, Christiansen FT, Mallal S: Predisposition to nevirapine hypersensitivity associated with HLA-DRB1*0101 and abrogated by low CD4 T-cell counts. AIDS 2005;19:97-99.

61 Phillips E, Lucas M, Keane N, Lucas A, McKinnon E, Mallal S: HLA-B*35 is associated with nevirapine hypersensitivity in the contemporary Western Australian HIV cohort study. 4th International Drug Hypersensitivity Meeting, April 22-25, 2010, Rome.

62 Chantarangsu S, Mushiroda T, Mahasirimongkol S, Kiertiburanakul S, Sungkanuparph S, Manosuthi W, Tantisiriwat W, Charoenyingwattana A, Sura T, Chantratita $\mathrm{W}$, Nakamura Y: HLA-B*3505 allele is a strong predictor for nevirapine-induced skin adverse drug reactions in HIV-infected Thai patients. Pharmacogenet Genomics 2009;19: 139-146.

63 Dickinson L, Chaponda M, Carr DF, van Oosterhout JJ, Kumwenda J, Lalloo DG, Pirmohamed M, Heyderman RS, Khoo SH: Population pharmacokinetic and pharmacogenetic analysis of nevirapine in hypersensitive and tolerant HIV-infected patients from Malawi. Antimicrob Agents Chemother 2014;58: 706-712.
64 Gatanaga H, Yazaki H, Tanuma J, Honda M, Genka I, Teruya K, Tachikawa N, Kikuchi Y, Oka S: HLA-Cw8 primarily associated with hypersensitivity to nevirapine. AIDS 2007;21: 264-265.

65 Littera R, Carcassi C, Masala A, Piano P, Serra P, Ortu F, Corso N, Casula B, La Nasa G, Contu L, Manconi PE: HLA-dependent hypersensitivity to nevirapine in Sardinian HIV patients. AIDS 2006;20:1621-1626.

66 Keane NM, Pavlos RK, McKinnon E, Lucas A, Rive C, Blyth CC, Dunn D, Lucas M, Mallal S, Phillips E: HLA class I restricted CD8+ and class II restricted CD4+ T cells are implicated in the pathogenesis of nevirapine hypersensitivity. AIDS 2014;28:1891-1901.

67 Caixas U, Antunes AM, Marinho AT, Godinho AL, Grilo NM, Marques MM, Oliveira MC, Branco T, Monteiro EC, Pereira SA: Evidence for nevirapine bioactivation in man: searching for the first step in the mechanism of nevirapine toxicity. Toxicology 2012;301: 33-39.

68 Chantarangsu S, Mushiroda T, Mahasirimongkol S, Kiertiburanakul S, Sungkanuparph S, Manosuthi W, Tantisiriwat W, Charoenyingwattana A, Sura T, Takahashi A, Kubo M, Kamatani N, Chantratita W, Nakamura Y: Genome-wide association study identifies variations in $6 \mathrm{p} 21.3$ associated with nevirapine-induced rash. Clin Infect Dis 2011;53: 341-348.

69 Amstutz U, Shear NH, Rieder MJ, Hwang S, Fung V, Nakamura H, Connolly MB, Ito S, Carleton BC; CPNDS Clinical Recommendation Group: Recommendations for HLA$B^{*}$ 15:02 and HLA-A*31:01 genetic testing to reduce the risk of carbamazepine-induced hypersensitivity reactions. Epilepsia 2014;55: 496-506.

70 Grover S, Kukreti R: HLA alleles and hypersensitivity to carbamazepine: an updated systematic review with meta-analysis. Pharmacogenet Genomics 2014;24:94-112.

71 Chung WH, Hung SI, Hong HS, Hsih MS, Yang LC, Ho HC, Wu JY, Chen YT: Medical genetics: a marker for Stevens-Johnson syndrome. Nature 2004;428:486.

72 Lonjou C, Thomas L, Borot N, Ledger N, de Toma C, LeLouet H, Graf E, Schumacher M, Hovnanian A, Mockenhaupt M, Roujeau JC: A marker for Stevens-Johnson syndrome ...: ethnicity matters. Pharmacogenomics J 2006; 6:265-268.

73 McCormack M, Alfirevic A, Bourgeois S, Farrell JJ, Kasperaviciute D, Carrington M, Sills GJ, Marson T, Jia X, de Bakker PI, Chinthapalli K, Molokhia M, Johnson MR, O’Connor GD, Chaila E, Alhusaini S, Shianna KV, Radtke RA, Heinzen EL, Walley N, Pandolfo M, Pichler W, Park BK, Depondt C, Sisodiya SM, Goldstein DB, Deloukas P, Delanty N, Cavalleri GL, Pirmohamed M: HLA-A*3101 and carbamazepine-induced hypersensitivity reactions in Europeans. N Engl J Med 2011; 364:1134-1143. 
74 Ozeki T, Mushiroda T, Yowang A, Takahashi A, Kubo M, Shirakata Y, Ikezawa Z, Iijima M, Shiohara T, Hashimoto K, Kamatani N, Nakamura Y: Genome-wide association study identifies HLA-A*3101 allele as a genetic risk factor for carbamazepine-induced cutaneous adverse drug reactions in Japanese population. Hum Mol Genet 2011;20:1034-1041.

75 Genin E, Chen DP, Hung SI, Sekula P, Schumacher M, Chang PY, Tsai SH, Wu TL, Bellon T, Tamouza R, Fortier C, Toubert A, Charron D, Hovnanian A, Wolkenstein P, Chung WH, Mockenhaupt M, Roujeau JC: HLA-A*31:01 and different types of carbamazepine-induced severe cutaneous adverse reactions: an international study and meta-analysis. Pharmacogenomics J 2014;14:281-288.

76 Hsiao YH, Hui RC, Wu T, Chang WC, Hsih MS, Yang $\mathrm{CH}$, Ho HC, Chang YG, Chen MJ, Lin JY, Chen DP, Chang PY, Wu TL, Hung SI, Chung WH: Genotype-phenotype association between HLA and carbamazepine-induced hypersensitivity reactions: strength and clinical correlations. J Dermatol Sci 2014; 73:101-109.

77 Locharernkul C, Shotelersuk V, Hirankarn N: Pharmacogenetic screening of carbamazepine-induced severe cutaneous allergic reactions. J Clin Neurosci 2011;18:1289-1294.

78 Plumpton CO, Yip VL, Alfirevic A, Marson AG, Pirmohamed M, Hughes DA: Cost-effectiveness of screening for HLA-A*31:01 prior to initiation of carbamazepine in epilepsy. Epilepsia 2015;56:556-563.

79 Wei CY, Chung WH, Huang HW, Chen YT, Hung SI: Direct interaction between HLA-B and carbamazepine activates $\mathrm{T}$ cells in patients with Stevens-Johnson syndrome. J Allergy Clin Immunol 2012;129:1562.e51569.e5.

80 Ko TM, Chung WH, Wei CY, Shih HY, Chen JK, Lin CH, Chen YT, Hung SI: Shared and restricted T-cell receptor use is crucial for carbamazepine-induced Stevens-Johnson syndrome. J Allergy Clin Immunol 2011;128: 1266.e11-1276.e11.

81 Jarjour S, Barrette M, Normand V, Rouleau JL, Dubé MP, de Denus S: Genetic markers associated with cutaneous adverse drug reactions to allopurinol: a systematic review. Pharmacogenomics 2015;16:755-767.

82 Ramasamy SN, Korb-Wells CS, Kannangara DR, Smith MW, Wang N, Roberts DM, Graham GG, Williams KM, Day RO: Allopurinol hypersensitivity: a systematic review of all published cases, 1950-2012. Drug Saf 2013; 36:953-980.

83 Hung SI, Chung WH, Liou LB, Chu CC, Lin M, Huang HP, Lin YL, Lan JL, Yang LC, Hong HS, Chen MJ, Lai PC, Wu MS, Chu CY, Wang $\mathrm{KH}$, Chen $\mathrm{CH}$, Fann CS, Wu JY, Chen YT: HLA-B*5801 allele as a genetic marker for severe cutaneous adverse reactions caused by allopurinol. Proc Natl Acad Sci USA 2005; 102:4134-4139.
84 Tassaneeyakul W, Jantararoungtong T, Chen P, Lin PY, Tiamkao S, Khunarkornsiri U, Chucherd P, Konyoung P, Vannaprasaht S, Choonhakarn C, Pisuttimarn P, Sangviroon A, Tassaneeyakul W: Strong association between HLA-B*5801 and allopurinol-induced Stevens-Johnson syndrome and toxic epidermal necrolysis in a Thai population. Pharmacogenet Genomics 2009;19:704-709.

85 Kaniwa N, Saito Y, Aihara M, Matsunaga K, Tohkin M, Kurose K, Sawada J, Furuya H, Takahashi Y, Muramatsu M, Kinoshita S, Abe M, Ikeda H, Kashiwagi M, Song Y, Ueta M, Sotozono C, Ikezawa Z, Hasegawa R; JSAR Research Group: HLA-B locus in Japanese patients with anti-epileptics and allopurinol-related Stevens-Johnson syndrome and toxic epidermal necrolysis. Pharmacogenomics 2008;9:1617-1622.

86 Kang HR, Jee YK, Kim YS, Lee CH, Jung JW, Kim SH, Park HW, Chang YS, Jang IJ, Cho SH, Min KU, Lee KW: Positive and negative associations of HLA class I alleles with allopurinol-induced scars in Koreans. Pharmacogenet Genomics 2011;21:303-307.

87 Lonjou C, Borot N, Sekula P, Ledger N, Thomas L, Halevy S, Naldi L, Bouwes-Bavinck JN, Sidoroff A, de Toma C, Schumacher M, Roujeau JC, Hovnanian A, Mockenhaupt M: A European study of HLA-B in Stevens-Johnson syndrome and toxic epidermal necrolysis related to five high-risk drugs. Pharmacogenet Genomics 2008;18:99-107.

88 Gonçalo M, Coutinho I, Teixeira V, Gameiro AR, Brites MM, Nunes R, Martinho A: HLA$B * 58: 01$ is a risk factor for allopurinol-induced DRESS and Stevens-Johnson syndrome/toxic epidermal necrolysis in a Portuguese population. Br J Dermatol 2013;169: 660-665.

89 Yeo SI: HLA-B*5801: utility and cost-effectiveness in the Asia-Pacific region. Int J Rheum Dis 2013;16:254-257.

90 Saokaew S, Tassaneeyakul W, Maenthaisong $\mathrm{R}$, Chaiyakunapruk N: Cost-effectiveness analysis of HLA-B*5801 testing in preventing allopurinol-induced SJS/TEN in Thai population. PLoS One 2014;9:e94294.

91 Somkrua R, Eickman EE, Saokaew S, Lohitnavy $M$, Chaiyakunapruk N: Association of HLA-B*5801 allele and allopurinol-induced Stevens Johnson syndrome and toxic epidermal necrolysis: a systematic review and metaanalysis. BMC Med Genet 2011;12:118.

92 Genin E, Schumacher M, Roujeau JC, Naldi L, Liss Y, Kazma R, Sekula P, Hovnanian A, Mockenhaupt M: Genome-wide association study of Stevens-Johnson syndrome and toxic epidermal necrolysis in Europe. Orphanet J Rare Dis 2011;6:52.

93 Jung JW, Kim JY, Yoon SS, Cho SH, Park SY, Kang HR: HLA-DR9 and DR14 are associated with the allopurinol-induced hypersensitivity in hematologic malignancy. Tohoku J Exp Med 2014;233:95-102.
94 Yun J, Mattsson J, Schnyder K, Fontana S, Largiader CR, Pichler WJ, Yerly D: Allopurinol hypersensitivity is primarily mediated by dose-dependent oxypurinol-specific $\mathrm{T}$ cell response. Clin Exp Allergy 2013;43: 1246-1255.

95 Yun J, Marcaida MJ, Eriksson KK, Jamin H, Fontana S, Pichler WJ, Yerly D: Oxypurinol directly and immediately activates the drugspecific $T$ cells via the preferential use of HLA-B*58:01. J Immunol 2014;192:29842993.

96 Chung WH, Pan RY, Chu MT, Chin SW, Huang YL, Wang WC, Chang JY, Hung SI: Oxypurinol-specific $\mathrm{T}$ cells possess preferential TCR clonotypes and express granulysin in allopurinol-induced severe cutaneous adverse reactions. J Invest Dermatol 2015; 135:2237-2248.

97 Chung WH, Chang WC, Stocker SL, Juo CG, Graham GG, Lee MH, Williams KM, Tian YC, Juan KC, Jan Wu YJ, Yang CH, Chang CJ, Lin YJ, Day RO, Hung SI: Insights into the poor prognosis of allopurinol-induced severe cutaneous adverse reactions: the impact of renal insufficiency, high plasma levels of oxypurinol and granulysin. Ann Rheum Dis 2015;74:2157-2164.

98 Jung JW, Kim DK, Park HW, Oh KH, Joo KW, Kim YS, Ahn C, Lee KW, Cho SH, Min KU, Kang HR: An effective strategy to prevent allopurinol-induced hypersensitivity by HLA typing. Genet Med 2015;17:807814.

99 Pavlos R, Mallal S, Phillips E: HLA and pharmacogenetics of drug hypersensitivity. Pharmacogenomics 2012;13:1285-1306.

100 Profaizer T, Eckels D: HLA alleles and drug hypersensitivity reactions. Int J Immunogenet 2012;39:99-105.

101 Dunn PP: Human leucocyte antigen typing: techniques and technology, a critical appraisal. Int J Immunogenet 2011;38:463473.

102 De Spiegelaere W, Philippe J, Vervisch K, Verhofstede C, Malatinkova E, Kiselinova M, Trypsteen W, Bonczkowski P, Vogelaers D, Callens S, Ruelle J, Kabeya K, De Wit S, Van Acker P, Van Sandt V, Emonds MP, Coucke P, Sermijn E, Vandekerckhove L: Comparison of methods for in-house screening of HLA-B*57:01 to prevent abacavir hypersensitivity in HIV-1 care. PLoS One 2015;10:e0123525.

103 Dello Russo C, Lisi L, Fabbiani M, Gagliardi D, Fanti I, Di Giambenedetto S, Cauda R, Navarra P: Detection of HLA-B*57:01 by real-time PCR: implementation into routine clinical practice and additional validation data. Pharmacogenomics 2014;15:319-327.

104 Rodriguez-Novoa S, Cuenca L, Morello J, Cordoba M, Blanco F, Jimenez-Nacher I, Soriano V: Use of the HCP5 single nucleotide polymorphism to predict hypersensitivity reactions to abacavir: correlation with HLAB*5701. J Antimicrob Chemother 2010;65: 1567-1569. 
105 Maekawa K, Nishikawa J, Kaniwa N, Sugiyama E, Koizumi T, Kurose K, Tohkin M, Saito Y: Development of a rapid and inexpensive assay for detecting a surrogate genetic polymorphism of HLA-B*58:01: a partially predictive but useful biomarker for allopurinol-related Stevens-Johnson syndrome/toxic epidermal necrolysis in Japanese. Drug Metab Pharmacokinet 2012;27: 447-450.

106 Kwok J, Kwong KM: Loop-mediated isothermal amplification for detection of HLAB*58:01 allele. Tissue antigens 2013;81:8392.

107 Kostenko L, Kjer-Nielsen L, Nicholson I, Hudson F, Lucas A, Foley B, Chen K, Lynch K, Nguyen J, Wu AH, Tait BD, Holdsworth R, Mallal S, Rossjohn J, Bharadwaj M, McCluskey J: Rapid screening for the detection of HLA-B57 and HLA-B58 in prevention of drug hypersensitivity. Tissue Antigens 2011; 78:11-20.

108 Cristallo AF, Schroeder J, Citterio A, Santori G, Ferrioli GM, Rossi U, Bertani G, Cassano S, Gottardi P, Ceschini N, Barocci F, Ribizzi G, Cutrupi V, Cairoli R, Rapisarda V, Pastorello EA, Barocci S: A study of HLA class I and class II 4-digit allele level in Stevens-Johnson syndrome and toxic epidermal necrolysis. Int J Immunogenet 2011;38: 303-309.

109 Niihara H, Kaneko S, Ito T, Sugamori T, Takahashi N, Kohno K, Morita E: HLAB*58:01 strongly associates with allopurinol-induced adverse drug reactions in a Japanese sample population. J Dermatol Sci 2013;71:150-152.

110 Lucena MI, Molokhia M, Shen Y, Urban TJ, Aithal GP, Andrade RJ, Day CP, Ruiz-Cabello F, Donaldson PT, Stephens C, Pirmohamed M, Romero-Gomez M, Navarro JM, Fontana RJ, Miller M, Groome M, BondonGuitton E, Conforti A, Stricker BH, Carvajal A, Ibanez L, Yue QY, Eichelbaum M, Floratos A, Pe'er I, Daly MJ, Goldstein DB, Dillon JF, Nelson MR, Watkins PB, Daly AK, Spanish DILI Registry, EUDRAGENE, DILIN, DILIGEN, International SAEC: Susceptibility to amoxicillin-clavulanate-induced liver injury is influenced by multiple HLA class I and II alleles. Gastroenterology 2011;141: 338-347.

111 Stephens C, Lopez-Nevot MA, Ruiz-Cabello F, Ulzurrun E, Soriano G, Romero-Gomez M, Moreno-Casares A, Lucena MI, Andrade RJ: HLA alleles influence the clinical signature of amoxicillin-clavulanate hepatotoxicity. PLoS One 2013;8:e68111.

112 Hautekeete ML, Horsmans Y, Van Waeyenberge C, Demanet C, Henrion J, Verbist L, Brenard R, Sempoux C, Michielsen PP, Yap PS, Rahier J, Geubel AP: HLA association of amoxicillin-clavulanate-induced hepatitis. Gastroenterology 1999;117:1181-1186.
113 Kim SH, Lee SK, Kim SH, Park HW, Chang YS, Lee KW, Jee YK: Antituberculosis druginduced hypersensitivity syndrome and its association with human leukocyte antigen. Tuberculosis (Edinb) 2013;93:270-274.

114 Alfirevic A, Jorgensen AL, Williamson PR, Chadwick DW, Park BK, Pirmohamed M: HLA-B locus in Caucasian patients with carbamazepine hypersensitivity. Pharmacogenomics 2006;7:813-818.

115 Li LJ, Hu FY, Wu XT, An DM, Yan B, Zhou D: Predictive markers for carbamazepine and lamotrigine-induced maculopapular exanthema in Han Chinese. Epilepsy Res 2013;106:296-300.

116 Hung SI, Chung WH, Jee SH, Chen WC, Chang YT, Lee WR, Hu SL, Wu MT, Chen GS, Wong TW, Hsiao PF, Chen WH, Shih HY, Fang WH, Wei CY, Lou YH, Huang YL, Lin JJ, Chen YT: Genetic susceptibility to carbamazepine-induced cutaneous adverse drug reactions. Pharmacogenet Genomics 2006;16:297-306.

117 He XJ, Jian LY, He XL, Wu Y, Xu YY, Sun XJ, Miao LY, Zhao LM: Association between the HLA-B*15:02 allele and carbamazepineinduced Stevens-Johnson syndrome/toxic epidermal necrolysis in Han individuals of northeastern China. Pharmacol Rep 2013; 65:1256-1262.

118 Tangamornsuksan W, Chaiyakunapruk N, Somkrua R, Lohitnavy M, Tassaneeyakul W: Relationship between the HLA-B*1502 allele and carbamazepine-induced StevensJohnson syndrome and toxic epidermal necrolysis: a systematic review and metaanalysis. JAMA Dermatol 2013;149:10251032.

119 Shi YW, Min FL, Qin B, Zou X, Liu XR, Gao MM, Wang Q, Zhou JQ, Liao WP: Association between HLA and Stevens-Johnson syndrome induced by carbamazepine in southern Han Chinese: genetic markers besides B*1502? Basic Clin Pharmacol Toxicol 2012;111:58-64.

120 Khor AH, Lim KS, Tan CT, Wong SM, Ng CC: HLA-B*15:02 association with carbamazepine-induced Stevens-Johnson syndrome and toxic epidermal necrolysis in an Indian population: a pooled-data analysis and meta-analysis. Epilepsia 2014;55:e120e124.

121 Niihara H, Kakamu T, Fujita Y, Kaneko S, Morita E: HLA-A31 strongly associates with carbamazepine-induced adverse drug reactions but not with carbamazepine-induced lymphocyte proliferation in a Japanese population. J Dermatol 2012;39:594-601.

122 Kaniwa N, Saito Y, Aihara M, Matsunaga K, Tohkin M, Kurose K, Furuya H, Takahashi Y, Muramatsu M, Kinoshita S, Abe M, Ikeda H, Kashiwagi M, Song Y, Ueta M, Sotozono C, Ikezawa Z, Hasegawa R: HLA-B*1511 is a risk factor for carbamazepine-induced Stevens-Johnson syndrome and toxic epidermal necrolysis in Japanese patients. Epilepsia 2010;51:2461-2465.
123 Kashiwagi M, Aihara M, Takahashi Y, Yamazaki E, Yamane Y, Song Y, Muramatsu M, Ikezawa Z: Human leukocyte antigen genotypes in carbamazepine-induced severe cutaneous adverse drug response in Japanese patients. J Dermatol 2008;35:683-685.

124 Kim SH, Lee KW, Song WJ, Kim SH, Jee YK, Lee SM, Kang HR, Park HW, Cho SH, Park $\mathrm{SH}$, Min KU, Chang YS: Carbamazepineinduced severe cutaneous adverse reactions and HLA genotypes in Koreans. Epilepsy Res 2011;97:190-197.

125 Chang CC, Too CL, Murad S, Hussein SH: Association of HLA-B*1502 allele with carbamazepine-induced toxic epidermal necrolysis and Stevens-Johnson syndrome in the multi-ethnic Malaysian population. Int J Dermatol 2011;50:221-224.

126 Nguyen DV, Chu HC, Nguyen DV, Phan $\mathrm{MH}$, Craig T, Baumgart $\mathrm{K}$, van Nunen S: HLA-B*1502 and carbamazepine-induced severe cutaneous adverse drug reactions in Vietnamese. Asia Pac Allergy 2015;5:68-77.

127 Zhang FR, Liu H, Irwanto A, Fu XA, Li Y, Yu GQ, Yu YX, Chen MF, Low HQ, Li JH, Bao FF, Foo JN, Bei JX, Jia XM, Liu J, Liany H, Wang N, Niu GY, Wang ZZ, Shi BQ, Tian HQ, Liu HX, Ma SS, Zhou Y, You JB, Yang Q, Wang C, Chu TS, Liu DC, Yu XL, Sun $Y H$, Ning Y, Wei ZH, Chen SL, Chen XC, Zhang ZX, Liu YX, Pulit SL, Wu WB, Zheng ZY, Yang RD, Long H, Liu ZS, Wang JQ, Li $\mathrm{M}$, Zhang LH, Wang $\mathrm{H}$, Wang LM, Xiao $\mathrm{P}$, Li JL, Huang ZM, Huang JX, Li Z, Liu J, Xiong L, Yang J, Wang XD, Yu DB, Lu XM, Zhou GZ, Yan LB, Shen JP, Zhang GC, Zeng YX, de Bakker PI, Chen SM, Liu JJ: HLA$\mathrm{B}^{*} 13: 01$ and the dapsone hypersensitivity syndrome. N Engl J Med 2013;369:16201628.

128 Daly AK, Donaldson PT, Bhatnagar P, Shen Y, Pe'er I, Floratos A, Daly MJ, Goldstein DB, John S, Nelson MR, Graham J, Park BK, Dillon JF, Bernal W, Cordell HJ, Pirmohamed M, Aithal GP, Day CP: DILIGEN Study, International SAE Consortium: HLA-B*5701 genotype is a major determinant of drug-induced liver injury due to flucloxacillin. Nat Genet 2009;41:816-819.

129 Kazeem GR, Cox C, Aponte J, Messenheimer J, Brazell C, Nelsen AC, Nelson MR, Foot E: High-resolution HLA genotyping and severe cutaneous adverse reactions in lamotrigine-treated patients. Pharmacogenet Genomics 2009;19:661-665.

130 Hung SI, Chung WH, Liu ZS, Chen $\mathrm{CH}$ Hsih MS, Hui RC, Chu CY, Chen YT: Common risk allele in aromatic antiepilepticdrug induced Stevens-Johnson syndrome and toxic epidermal necrolysis in Han Chinese. Pharmacogenomics 2010;11:349-356.

131 Shi YW, Min FL, Liu XR, Zan LX, Gao MM, Yu MJ, Liao WP: HLA-B alleles and lamotrigine-induced cutaneous adverse drug reactions in the Han Chinese population. Basic Clin Pharmacol Toxicol 2011;109:4246. 
132 Spraggs CF, Budde LR, Briley LP, Bing N, Cox CJ, King KS, Whittaker JC, Mooser VE, Preston AJ, Stein SH, Cardon LR: HLADQA $1 * 02: 01$ is a major risk factor for lapatinib-induced hepatotoxicity in women with advanced breast cancer. J Clin Oncol 2011; 29:667-673.

133 Schaid DJ, Spraggs CF, McDonnell SK, Parham LR, Cox CJ, Ejlertsen B, Finkelstein DM, Rappold E, Curran J, Cardon LR, Goss PE: Prospective validation of HLADRB $1 * 07: 01$ allele carriage as a predictive risk factor for lapatinib-induced liver injury. J Clin Oncol 2014;32:2296-2303.

134 Singer JB, Lewitzky S, Leroy E, Yang F, Zhao X, Klickstein L, Wright TM, Meyer J, Paulding CA: A genome-wide study identifies HLA alleles associated with lumiracoxib-related liver injury. Nat Genet 2010;42:711714.

135 Yang F, Xuan J, Chen J, Zhong H, Luo H, Zhou P, Sun X, He L, Chen S, Cao Z, Luo X, Xing Q: HLA-B*59:01: a marker for StevensJohnson syndrome/toxic epidermal necrolysis caused by methazolamide in Han Chinese. Pharmacogenomics J 2016;16:83-87.

136 Kim SH, Kim M, Lee KW, Kim SH, Kang HR, Park HW, Jee YK: HLA-B*5901 is strongly associated with methazolamideinduced Stevens-Johnson syndrome/toxic epidermal necrolysis. Pharmacogenomics 2010;11:879-884.

137 Carr DF, Chaponda M, Jorgensen AL, Castro EC, van Oosterhout JJ, Khoo SH, Lalloo DG, Heyderman RS, Alfirevic A, Pirmohamed M: Association of human leukocyte antigen alleles and nevirapine hypersensitivity in a Malawian HIV-infected population. Clin Infect Dis 2013;56:1330-1339.

138 Vitezica ZG, Milpied B, Lonjou C, Borot N, Ledger TN, Lefebvre A, Hovnanian A: HLADRB $1 * 01$ associated with cutaneous hypersensitivity induced by nevirapine and efavirenz. AIDS 2008;22:540-541.

139 Yuan J, Guo S, Hall D, Cammett AM, Jayadev S, Distel M, Storfer S, Huang Z, Mootsikapun P, Ruxrungtham K, Podzamczer D, Haas DW; Nevirapine Toxicogenomics Study Team: Toxicogenomics of nevirapine-associated cutaneous and hepatic ad- verse events among populations of African, Asian, and European descent. AIDS 2011; 25:1271-1280

140 Gao S, Gui XE, Liang K, Liu Z, Hu J, Dong B: HLA-dependent hypersensitivity reaction to nevirapine in Chinese Han HIV-infected patients. AIDS Res Hum Retroviruses 2012; 28:540-543.

141 Umapathy S, Pawar A, Bajpai S, Pazare AR, Ghosh K: HLA involvement in nevirapineinduced dermatological reaction in antiretroviral-treated HIV-1 patients. J Pharmacol Pharmacother 2011;2:114-115.

142 Phillips E, Bartlett JA, Sanne I, Lederman MM, Hinkle J, Rousseau F, Dunn D, Pavlos R, James I, Mallal SA, Haas DW: Associations between HLA-DRB ${ }^{*} 0102$, HLAB*5801, and hepatotoxicity during initiation of nevirapine-containing regimens in South Africa. J Acquir Immune Defic Syndr 2013; 62:e55-e57.

143 Likanonsakul S, Rattanatham T, Feangvad S, Uttayamakul S, Prasithsirikul W, Tunthanathip P, Nakayama EE, Shioda T: HLA$\mathrm{Cw}^{*} 04$ allele associated with nevirapine-induced rash in HIV-infected Thai patients. AIDS Res Ther 2009;6:22.

144 Ueta M, Kannabiran C, Wakamatsu TH, Kim MK, Yoon KC, Seo KY, Joo CK, Sangwan V, Rathi V, Basu S, Shamaila A, Lee HS, Yoon S, Sotozono C, Gomes JA, Tokunaga K, Kinoshita S: Trans-ethnic study confirmed independent associations of HLA$\mathrm{A}^{*}$ 02:06 and HLA-B*44:03 with cold medicine-related Stevens-Johnson syndrome with severe ocular surface complications. Sci Rep 2014;4:5981.

145 Ueta M, Kaniwa N, Sotozono C, Tokunaga K, Saito Y, Sawai H, Miyadera H, Sugiyama E, Maekawa K, Nakamura R, Nagato M, Aihara M, Matsunaga K, Takahashi Y, Furuya H, Muramatsu M, Ikezawa Z, Kinoshita S: Independent strong association of HLA$\mathrm{A}^{*} 02: 06$ and HLA-B*44:03 with cold medicine-related Stevens-Johnson syndrome with severe mucosal involvement. Sci Rep 2014;4:4862.

146 He N, Min FL, Shi YW, Guo J, Liu XR, Li BM, Zhou JH, Ou YM, Liao JX, Liao WP: Cutaneous reactions induced by oxcarbaze- pine in Southern Han Chinese: incidence, features, risk factors and relation to HLA-B alleles. Seizure 2012;21:614-618.

$147 \mathrm{Hu} F Y$, Wu XT, An DM, Yan B, Stefan H, Zhou D: Pilot association study of oxcarbazepine-induced mild cutaneous adverse reactions with HLA-B*1502 allele in Chinese Han population. Seizure 2011;20:160 162.

148 Lv YD, Min FL, Liao WP, He N, Zeng T, Ma DH, Shi YW: The association between oxcarbazepine-induced maculopapular eruption and HLA-B alleles in a northern Han Chinese population. BMC Neurol 2013;13: 75.

149 Locharernkul C, Loplumlert J, Limotai C, Korkij W, Desudchit T, Tongkobpetch S, Kangwanshiratada O, Hirankarn N, Suphapeetiporn K, Shotelersuk V: Carbamazepine and phenytoin induced Stevens-Johnson syndrome is associated with HLA-B*1502 allele in Thai population. Epilepsia 2008;49: 2087-2091.

150 Kongpan T, Mahasirimongkol S, Konyoung P, Kanjanawart S, Chumworathayi P, Wichukchinda N, Kidkeukarun R, Preechakul S, Khunarkornsiri U, Bamrungram W, Supharatwattanakun B, Mootsikapun P, Kwangsukstid S, Denjanta S, Vannaprasaht S, Rungapiromnan W, Suwankesawong W, Tassaneeyakul W, Tassaneeyakul W: Candidate HLA genes for prediction of co-trimoxazole-induced severe cutaneous reactions. Pharmacogenet Genomics 2015;25:402411.

151 Yang F, Gu B, Zhang L, Xuan J, Luo H, Zhou P, Zhu Q, Yan S, Chen SA, Cao Z, Xu J, Xing Q, Luo X: HLA-B*13:01 is associated with salazosulfapyridine-induced drug rash with eosinophilia and systemic symptoms in Chinese Han population. Pharmacogenomics 2014;15:1461-1469.

152 Hirata K, Takagi H, Yamamoto M, Matsumoto T, Nishiya T, Mori K, Shimizu S, Masumoto H, Okutani Y: Ticlopidine-induced hepatotoxicity is associated with specific human leukocyte antigen genomic subtypes in Japanese patients: a preliminary case-control study. Pharmacogenomics J 2008;8:2933. 